\title{
Origin and Evolution of Saline Spring Water in North and Central Laos Based on Hydrochemistry and Stable Isotopes $(\delta \mathrm{D}$, $\delta^{18} \mathrm{O}, \delta^{11} \mathrm{~B}$, and $\left.\delta^{37} \mathrm{Cl}\right)$
}

\author{
Xiwei Qin ${ }^{1,2,3, * \mathbb{D}}$, Haizhou Ma ${ }^{2,3, *}$, Xiying Zhang ${ }^{2,3}$, Xiasong $\mathrm{Hu}^{1}$, Guorong $\mathrm{Li}^{1}{ }^{1}$, Ziwen Jiang ${ }^{1}$, \\ Huaide Cheng ${ }^{2,3}$, Jibin Han ${ }^{2,3}$, Yongshou Li ${ }^{2,3}$, Weiliang Miao ${ }^{2,3}$, Wenhua Han ${ }^{2,3}$, Sha Yang ${ }^{1}$, Qian Song ${ }^{1}$, \\ Shang Lei ${ }^{1}$ and Hongying Wang ${ }^{1}$
}

check for updates

Citation: Qin, X.; Ma, H.; Zhang, X.; Hu, X.; Li, G.; Jiang, Z.; Cheng, H.; Han, J.; Li, Y.; Miao, W.; et al. Origin and Evolution of Saline Spring Water in North and Central Laos Based on Hydrochemistry and Stable Isotopes $\left(\delta \mathrm{D}, \delta^{18} \mathrm{O}, \delta^{11} \mathrm{~B}\right.$, and $\left.\delta^{37} \mathrm{Cl}\right)$. Water 2021, 13, 3568. https://doi.org/ $10.3390 /$ w13243568

Academic Editors: R.V. Krishnamurthy and Elias Dimitriou

Received: 13 November 2021 Accepted: 8 December 2021 Published: 13 December 2021

Publisher's Note: MDPI stays neutral with regard to jurisdictional claims in published maps and institutional affiliations.

Copyright: (c) 2021 by the authors. Licensee MDPI, Basel, Switzerland. This article is an open access article distributed under the terms and conditions of the Creative Commons Attribution (CC BY) license (https:/ / creativecommons.org/licenses/by/ $4.0 /)$.
1 Department of Geological Engineering, Qinghai University, Xining 810016, China; huxiasong@sina.com (X.H.); qdliguorong@163.com (G.L.); jiangziwen0601@163.com (Z.J.); yangsha87@yeah.net (S.Y.); songqianqian_850@163.com (Q.S.); Leiciousls@163.com (S.L.); w18597011917@163.com (H.W.)

2 Key Laboratory of Comprehensive and Highly Efficient Utilization of Salt Lake Resources, Qinghai Institute of Salt Lakes, Northwest Institute of Eco-Environment and Resources, Chinese Academy of Sciences, Xining 810008, China; xyzhchina@isl.ac.cn (X.Z.); chenghuaide@isl.ac.cn (H.C.); jbhan@isl.ac.cn (J.H.); yongshouli@isl.ac.cn (Y.L.); weiliangm@isl.ac.cn (W.M.); hanwenhua@isl.ac.cn (W.H.)

3 Key Laboratory of Salt Lake Geology and Environment of Qinghai Province, Qinghai Institute of Salt Lakes, Northwest Institute of Eco-Environment and Resources, Chinese Academy of Sciences, Xining 810008, China

* Correspondence: qinxiwei0038@126.com (X.Q.); haizhou@isl.ac.cn (H.M.); Tel.: +86-138-9741-8165 (X.Q.); +86-139-0971-3049 (H.M.)

Abstract: This paper discusses the origin and evolution of saline springs in north and central Laos, based on chemical and stable isotopes $\left(\delta \mathrm{D}, \delta^{18} \mathrm{O}, \delta^{11} \mathrm{~B}\right.$, and $\left.\delta^{37} \mathrm{Cl}\right)$. All the saline springs in this study are of the $\mathrm{Na}-\mathrm{Cl}$ geochemical type. The geochemical and water isotope values suggest that the saline springs in this study are mainly derived from meteoric water and/or ice and snow melt from the surrounding mountains and that they also experienced strong evaporation and intense rock-water interactions. The ionic ratios, characteristic coefficients, ternary $\mathrm{Ca}-\mathrm{SO}_{4}-\mathrm{HCO}_{3}$ phase diagrams, and saturation indices of minerals show that the dissolution of halite, sulfate, and carbonate rocks may be the solute sources for saline springs in this study, whereas the underground brines in the Thakhek potash mining area are geochemically influenced by the dissolution of carnallite and sylvite. The global geothermal $\delta^{11} \mathrm{~B}-\mathrm{Cl} / \mathrm{B}$ relationship and $\delta^{11} \mathrm{~B}$ values (5.50 to $36.01 \%$ ) of saline springs suggest a continental origin of B. This B is most likely derived from marine carbonate rocks and marine evaporates (gypsum and halite) of the late Cretaceous, which is similar to the saline springs of the Nangqen-Qamdo-Simao Salt Basin. The $\delta^{37} \mathrm{Cl}$ value $(-0.12$ to +0.79$)$ and the $\mathrm{Cl} / \mathrm{Br}$ ratio (4076 to 9853) show that dissolution of late cretaceous marine halite layers, atmospheric precipitation, and water-rock interactions between volcanic rocks, mudstones, and sandstone can restrict the $\delta^{37} \mathrm{Cl}$ values in saline springs. Results from silica geothermometry and multi-mineral equilibrium diagrams indicate that the reservoir temperatures for the saline springs range from $87-137^{\circ} \mathrm{C}$ and experience deep circulation. Hydrochemical characteristic coefficients suggest that saline springs in the Muang Say basin may have leached sylvinite and carnallite and that the potash exploration prospect in this area is relatively good.

Keywords: saline springs; stable isotopes; recharge and solute sources; reservoir temperatures; marine evaporites; potash exploration prospect

\section{Introduction}

The Khorat Plateau (see Figure 1B) is one of the world's most valuable targets for the exploitation of potassium salts, which contains Sakon Nakhon Basin and Khorat Basin. 
The Muang Say, Vientiane, and Khammouane salt basins, located 100-600 km north of the Khorat Plateau, include extensive and thick late Cretaceous continental red beds, evaporite deposits, and saline springs [1-5]. The composition of dissolved salts in salty groundwater and brines of saline springs can be used as an important indicator for hydrochemical prospecting and determination of the genesis of evaporites. Many geological studies, based on the geochemical properties of drill cores [6-8], have been conducted on the giant potash deposits in the Khorat Plateau and the Khammouane basin. Similar research has not yet been undertaken in the Muang Say and Vientiane basins that occur in north and central Laos, due to legal restrictions and environmental concerns. No detailed chemical and isotopic characteristics that can assist in determining the origin and evolution of the saline springs or for assessing the prospecting potential of these salt basins therefore exist. It is therefore of great theoretical and practical significance to systematically analyze the cyclic evolutionary process, recharge mechanisms, and solute sources of the saline springs, which will assist in understanding its metallogenic potential and the genesis of the evaporites. This paper discusses the origin and evolution of saline springs in north and central Laos, based on chemical and stable isotopes, including solute and recharge sources, reservoir temperatures, a spring circulation model, as well as new potash exploration prospects.

Spring hydrochemistry assists in understanding solute sources and reservoir temperatures. $\delta \mathrm{D}$ and $\delta^{18} \mathrm{O}$ are excellent tracers for determining water recharge sources, the route of water circulation, and water-rock interactions [9-13], which are the most important parameters to distinguish between atmospheric and oceanic origins of spring water. Seawater and brines have high concentrations of $\mathrm{Cl}$ and $\mathrm{B}$, and these two elements experience important isotopic fractionation during the formation and evolution of brines. $B$ is soluble in water and chemically active, which makes it an effective tracer for determining groundwater salinity sources. Because of the relatively large mass difference between ${ }^{10} \mathrm{~B}$ and ${ }^{11} \mathrm{~B}$ [14-16], boron isotopes are widely used for tracing the origins of salt lakes and brines [17-20], tracing the loop of ocean sediments [21], tracing the domestic wastewater [22-24], and analyzing the evolution of hydrothermal fluids [25-29]. Chlorine is a conservative hydrophilic element that has two stable isotopes, ${ }^{35} \mathrm{Cl}$ and ${ }^{37} \mathrm{Cl}$. These isotopes can be used to determine magmatic fluid in volcanic regions [30], the origin of salinity in fluid inclusions [31], water-rock interactions with rock alterations [32-36], to describe hydrothermal processes [37,38], and to assess crustal recycling in the mantle or ocean $[39,40]$. The fractionation of $\mathrm{Cl}$ isotopes during the migration of chlorine in water and salt mineral deposits has been researched extensively [41,42]. These studies indicate that the lighter isotope $\left({ }^{35} \mathrm{Cl}\right)$ is preferentially fractionated into the resin phase, whereas the heavier isotope $\left({ }^{37} \mathrm{Cl}\right)$ partitions into the aqueous phase during crystallization. $\mathrm{B}$ and $\mathrm{Cl}$ isotopes have been used to characterize hot springs and brines and as tracers to determine the solute source and formation environment of springs and evaporite deposits. These springs and evaporite deposits occur not only in China, for example, in the western Tarim Basin [43], the Yangbajing geothermal field, Tibet [44], and Southern Tibet [45], but also abroad, for example, in the Eastern Desert of Egypt [46], the Khammouane potash deposits in Laos [7], the Gulf Coast Basin of United States [47], Eastern Canada [48], and the Ibusuki coastal geothermal region in Japan [49]. Hydrochemistry and stable isotopes can therefore be used to analyze the origin and evolution of saline springs in this study.

The main goal of this study was to use the hydrogeochemical and isotopic characteristics $\left(\delta \mathrm{D}, \delta^{18} \mathrm{O}, \delta^{11} \mathrm{~B}\right.$, and $\left.\delta^{37} \mathrm{Cl}\right)$ of the saline springs to identify its recharge mechanisms, solute sources, circulation depth, and reservoir temperatures. The above data was used to develop a conceptual model of spring circulation and potash exploration prospects. The hydrochemical characteristics of the springs and evaporite deposits in this study area are also compared to results from saline springs and underground brines in the surrounding area (the Lanping-Simao basin, Krabi province, the Thailand and potash mining area, and central Laos), and $\delta^{11} \mathrm{~B}$ values in saline springs are compared to international geothermal systems. 


\section{Geological and Hydrogeological Setting}

The Southeast Asian continent contains the South China Block (SCB), the Indochina Block, the Sibumasu Block, the Sukhothai Block, and the Qamdo-Simao Block. These blocks are bounded by fault zones and sutures, including the Ailaoshan Suture, the Red River Fault, the Dien Bien Phu Fault, the Nan Suture, the Jinghong Suture, and the Song Ma Suture (Figure 1B). The heterogeneous collisions of these Gondwana-derived microcontinents that occurred during the Indosinian orogeny are closely linked with the closing of the Tethyan Ocean during the late Permian to early Triassic [50-52]. The Indosinian Block, one of the largest tectonic units in Southeast Asia, is the result of the collision between India and Asia during the Cenozoic [53]. It is bounded to the west by the Lincang, SukHothai Terrane, and the Inthanon Suture Zone and to the east by the Ailaoshan and Song Ma Sutures [54,55], which has also been transected by the Dien Bien Phu Fault and the Ailaoshan-Red River Fault [1]. The Qamdo-Simao Block extends west from the Jinghong and Nan Sutures to the Jinshajiang, Ailaoshan, and Song Ma Sutures in the east $[54,55]$. The Simao Basin that is located to the south of the Qamdo-Simao Block is a typical continental rift basin that formed during the Jurassic-Cretaceous period [56], during the collision with the SCB during the late Triassic [57] or late Permian-early Triassic [58].

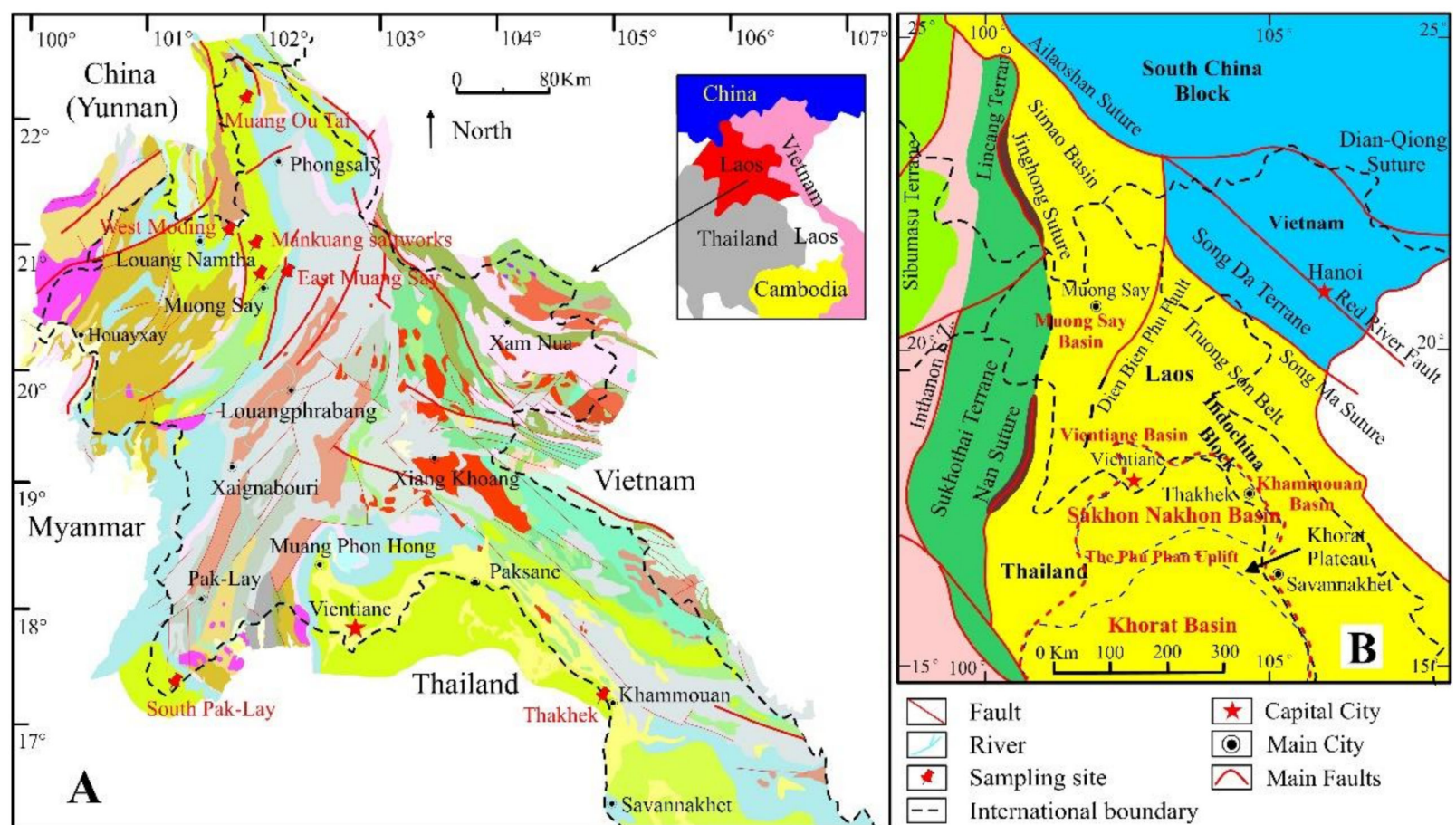

Qh Gravel, sandstone, clay $\mathrm{Q}$ Marine sediments $\mathrm{K}$ Siltstone, mudstone, shale, limestone and evaporates $\mathrm{N}$ Marine sediments

$\mathrm{E}$ Glutenite, limestone, mudstone, siltstone, volcanics $\mathrm{J}-\mathrm{K}$ Grao red beds: sandstone, siltstone, shale, limestone, dolomite, andesite, tuff

$\mathrm{J}$ Siltstonc, mudstonc, shale, limestone, argillaceous limestone $\mathrm{T}$ Marine sandstone, tuff sandstone, limestone, conglomerate, shale

P-T Conglomerate, sandstone, silty limestone, shale, basalt, andesite, tuff, slate D-C Phyllite, quartzite, shale, sandstone $\mathrm{rC}$ Granite

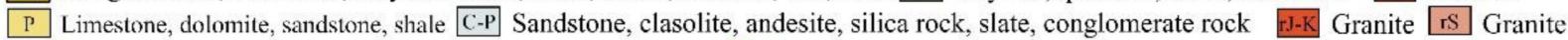

D Shale, flint, limestone, sandstone, clastic rocks, silica rock D Shale, flint, limestone, sandstone, clastic rock, siliceous rock

S-1) Quartzite, phyllite, schist, limestone, rhyolite, shale, tuff, carbonate rocks interspersed with clastic rocks EPz. Basic-ultrabasic rocks

o-S Conglomerate, sandstone, shale, flint, rhyolite, orthophyre, $\varepsilon$ Conglomerate, sandstone, shale, flint, rhyolite, orthophyre, limestone, limestone, basalt, andesite, fine clastic rock basalt, andesite, fine clastic rock

$\mathrm{E}-\mathrm{S}$ Siltstone, shale, dolomite, quartzite, flint, limestone, andesite, schist

Figure 1. (A). Geological sketch map and sampling sites in north and central Laos (modified from Geological map of Lao People's Democratic Republic, 1991) (B). Tectonic framework of central SE Asia showing the location of study area [54].

Laos is located in the northernmost part of the Indochina Peninsula. It is bordered by China's Yunnan to the north, Cambodia to the south, Vietnam to the east, Myanmar to the northwest, and Thailand to the southwest. The research area is in the north-central 
part of Laos, which includes the Muong Say Basin, Vientiane Basin, and Khammouane Basin. The magmatic and sedimentary rocks in northern Laos are mainly controlled by the Nan-Dien Bien Phu Suture Zone and the Truong Son Belt [1]. The Muong Say Basin is an important salt-bearing basin that connects the Simao and Vientiane basin, which is located between the Jinghong suture and the Dien Bien Phu fault [59]. The Mesozoic lithological association has typical lacustrine sedimentary characteristics $[51,60]$ and is similar to the late Cretaceous Mengyejing formation in the Simao Basin [60] (Figure 2). The Mengyejing Formation consists of three salt members from bottom to top and the lower part of the upper salt member contains an important sylvite layer. The Mesozoic outcrops in the Muong Say Basin [61] are characterized by purple and red continental mudstones that are interbedded with red siltstone sandstone and that are accompanied by mud conglomerates and gypsum. The Late Cretaceous continental red beds containing evaporites from the Muong Say Basin are also present in the Simao, Vientiane, and Khammouane Basins. These red beds are unconformably overlain by the late Cretaceous evaporites and clastic deposits [2-4]. The Vientiane and Khammouane Basins belong to the middle part of the Indochina block, and these two basin are located in the northern boundary of the Sakon Nakhon Basin. The Sakon Nakhon Basin is a subbasin of the Khorat Plateau (Figure 1B). The Khorat Plateau $\left(14^{\circ} 00^{\prime}-19^{\circ} 00^{\prime} \mathrm{N}, 101^{\circ} 00^{\prime}-106^{\circ} 00^{\prime} \mathrm{E}\right)$ is an area of $\sim 170,000 \mathrm{~km}^{2}$ in northeastern Thailand and central Laos and is bounded to the north by the Trung Son Tectonic Belt, to the northeast by the Song Da-Song Ma Suture and the South China Plate, to the south by the Wang Chao left-lateral strike-slip fault, and to the west by the Inthanon Suture and the Sibumasu Block [50,52,55,59] (Figure 1B). The Khorat Plateau has experienced a complex tectonic evolution, which included (1) the formation of semi-graben basins [55], which was caused by a series of tectonic events (including collision, thermal subsidence, stratigraphic inversion, stitching, and stretching between the Sibumasu block and the Indo-China block after late Cambrian); (2) the deposition of the nonmarine Khorat Group $\left(\mathrm{T}_{1}-\mathrm{K}_{1}\right)$ during the Mesozoic era [62,63]; (3) the deposition of marine salt-bearing strata (the Maha Sarakham Formation) in the late Cretaceous, which forms an unconformable contact with the underlying Khok Kruat Formation [64]; and (4) the uplift of the Phu Phan anticlinorium. The collision between the Indo-China Block, the Sibumasu Block, and the South China Block during the early Paleocene led to the uplift of the Phu Phan anticlinorium along the NW-SE direction, which divided the plateau into the Khorat Subbasin in the south and the Sakon Nakhon Subbasin in the north $[5,59,63,64]$ (Figure 1B). The Maha Sarakham Formation in northern-eastern Thailand, also named the Nong Box Formation in the Khammouane Basin and the Tabong Formation in the Vientiane Basin, central Laos [65], is an important salt-bearing stratum in the study area. The Maha Sarakham formation contains three distinctive salt-bearing members (upper, middle, and lower). Each salt-bearing member is composed of an evaporite unit and a clastic unit. The clastic unit is dominated by reddish to brown mudstone and muddy siltstone, while the evaporite unit in upper and middle salt-bearing members is typified by halite that is interbedded with laminated black-grey anhydrite or gypsum. The lower salt-bearing evaporite unit comprises five layers from top to bottom and is characterized by a potash layer (sylvite, carnallite, and minor boracite), which are colorless to smoky halite beds that are interbedded with off-white anhydrite stringers and form a sharp contact with the underlying early Cretaceous grey quartz sandstone [5] (Figure 2). The study area has a typical tropical monsoon climate. The Neogene-Quaternary strata in the study area form a porous aquifer, which is characterized by conglomerate, sandstone, and siltstone. The Cretaceous salt-bearing strata form a weak fractured aquifer and are composed of clastics and evaporates. Based on gravity prospecting, the NW-NE trending faults may act as potential water migration channels that cause surface and halite dissolution. Stratigraphy and depositional patterns indicate the existence of extensive and thick late Cretaceous continental red beds and evaporites, and the thickness of late Cretaceous saline stratigraphic units is about $3 \mathrm{~km}$. Underground saline springs within the study area can be used to study the genesis and metallogenic potential of these evaporites. 


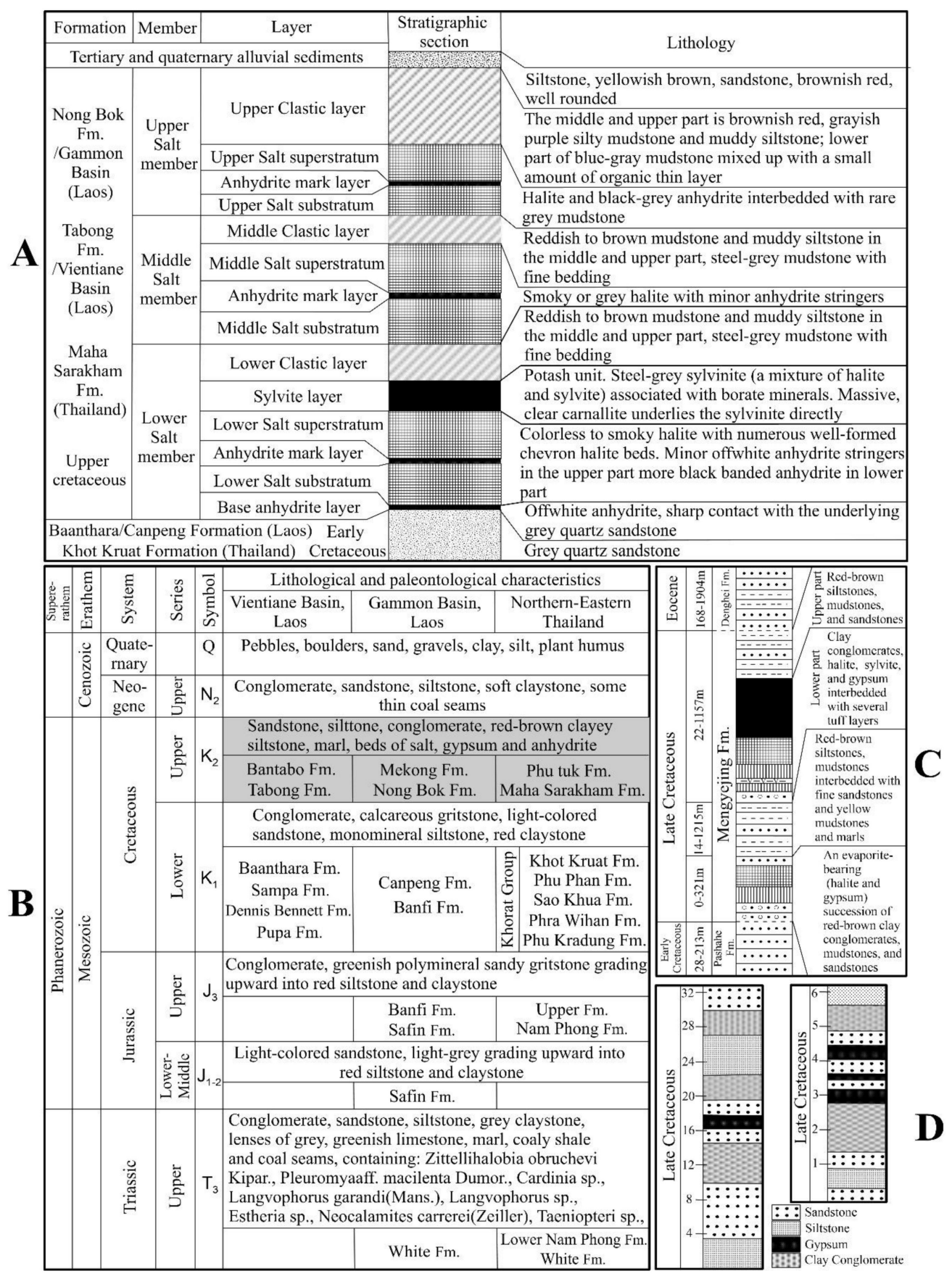

Figure 2. (A). Lithostratigraphy of the saliferous strata in the Laos and northeast Thailand [65]; (B). Phanerozoic stratigraphic correlation of Northeast Thailand-Vientiane Basin-Gammon Basin of Laos; (C). Lithostratigraphic column of the Mengyejing Formation in the Simao basin, southwestern China (modified from Wang et al., 2014); (D). Lithostratigraphic column of the Late Cretaceous section in the Muong Say Basin [65].

\section{Sampling and Methods}

Eight saline spring water samples were collected during the winter (January) of 2015. One sample each was collected at the Muang Ou Tai, West Moding, Mankuang Saltworks, South Pak-Lay, and Thakhek sampling sites, and three samples were collected in the Muang Say Basin (sea Figure 1A, Table 1).To compare the results of this study with neighboring regions, we consider the data of saline spring water and underground brines from the Khammouane Province in central Laos [66], the Simao Basin in the Yunnan Province, China [67,68], and the Krabi Province in Thailand [69]. 
The $\mathrm{pH}$ and temperature of the spring water were measured on-site using a Hach HQ40d portable meter. All the water samples were filtered through a $0.45-\mu \mathrm{m}$ membrane and preserved in clean HDPE bottles, except for the samples that were collected for $\mathrm{Cl}$ isotopic analysis. After filtration, the samples for cation analysis were acidified to $\mathrm{Ph}<2$ using ultrapure concentrated nitric acid. All the chemical analyses were conducted in the Qinghai Institute of Salt Lakes, at the Chinese Academy of Sciences. The samples were analysed for major cations ( $\mathrm{K}, \mathrm{Na}, \mathrm{Ca}$, and $\mathrm{Mg}$ ) and trace elements (Br, Sr, $\mathrm{Li}, \mathrm{B}, \mathrm{Si})$ using inductively coupled plasma optical emission spectroscopy (ICP-OES) and inductively coupled plasma mass spectrometry (ICP-MS). These methods have an analytical precision better than $0.1 \%$. Unfiltered water samples were analyzed for major anions $(\mathrm{F}, \mathrm{Cl}$, and $\mathrm{SO}_{4}$ ) using ion chromatography (IC; Dionex 120, Dionex, Sunnyvale, CA, USA) with an uncertainty of $< \pm 5 \%$. Major anions $\left(\mathrm{HCO}_{3}\right.$ and $\left.\mathrm{CO}_{3}\right)$ were determined via hydrochloric acid titration using phenolphthalein and a mixed solution of methylene blue and methyl red as indicators (with an uncertainty $< \pm 1 \%$ ). The hydrogen and oxygen isotopic compositions were measured using a MAT 253 stable isotope ratio mass spectrometer (Thermo Fisher Scientific, USA) at the National Research Center for Geoanalysis (NRCGA, PRC) located at the Chinese Academy of Geological Sciences. The $\delta \mathrm{D}$ and $\delta^{18} \mathrm{O}$ values are reported relative to the Vienna Standard Mean Ocean Water (VSMOW) isotopic standard. The respective precision for $\delta \mathrm{D}$ and $\delta^{18} \mathrm{O}$ were $\pm 3.0 \%$ and $\pm 0.2 \%$. The $\delta^{11} \mathrm{~B}$ and $\delta^{37} \mathrm{Cl}$ were measured at the Qinghai Institute of Salt Lakes at the Chinese Academy of Sciences using the P-TIMS method in a Triton thermal ionization mass spectrometer, which are based on an improved method for the high-precision isotopic measurement of boron and chlorine, with a precision of $\pm 0.3 \%$ for $\delta^{11} \mathrm{~B}$ and $\pm 0.2 \%$ for $\delta^{37} \mathrm{Cl}$ [70]. The sample preparation for the measurement of $\delta^{11} \mathrm{~B}$ included a two-column ion-exchange procedure $[16,18,71]$. Firstly, these saline spring water samples, containing about $10 \mu \mathrm{g}$ B and using $2 \mathrm{M} \mathrm{NH}_{4} \mathrm{OH}$ to remove cations, were passed through a coupled peristaltic pump coupled with a $0.8 \mathrm{~mL}$ Amberlite IRA 743 B-specific resin column. The amberlite IRA 743 B-specific resin was regenerated by $10 \mathrm{~mL}$ of $2 \mathrm{M} \mathrm{HCl}, 20 \mathrm{~mL}$ of pure water, and $10 \mathrm{~mL}$ of $\mathrm{NH}_{3} \cdot \mathrm{H}_{2} \mathrm{O}$ and was washed to neutral $\mathrm{pH}$ before use. The B was then eluted from the resin with $10 \mathrm{~mL} 75^{\circ} \mathrm{C}$ and $0.1 \mathrm{M} \mathrm{HCl}$, and the eluent was evaporated at $60^{\circ} \mathrm{C}$ to $0.5 \mathrm{~mL}$. Thereafter, the residue was diluted with pure water (low B water) and passed through a $0.15-\mathrm{mL}$ anion-cation mixed resin to further purify the sample and remove $\mathrm{HCl}$. Finally, $10 \mu \mathrm{g}$ mannitol was added to the eluent and vaporized to $0.3 \mathrm{~mL}$ at $60^{\circ} \mathrm{C}$ for mass spectrometry analysis. The measured ${ }^{11} \mathrm{~B} /{ }^{10} \mathrm{~B}$ value of NIST SRM 951 was $4.00514 \pm 0.1 \%$ o $(2 \delta, n=6)$. The analysis of $\mathrm{Cl}$ isotopic compositions and chemical separation of $\mathrm{Cl}$ followed the procedure as follows. All spring water samples were first passed through the $\mathrm{H}$-cation exchange resin column ( 300 mesh, resin type: Dowex $50 \mathrm{WX} 8$ ) to transform the $\mathrm{Cl}$ into a $\mathrm{HCl}$ solution and were then eluted through the Cs column to collect newly formed $\mathrm{CsCl}$ solutions [33,70]. About $10 \mu \mathrm{g}$ of $\mathrm{Cl}$ (as $\mathrm{CsCl}$ ) was loaded and dried onto a tantalum (Ta) filament. The Ta filament was heated under a vacuum system (using a current of $2.5 \mathrm{~A}$ for $1 \mathrm{~h}$ ) and was covered with $2.5 \mu \mathrm{L}$ of graphite slurry ( $80 \%$ of ethanol plus $80 \mu \mathrm{g}$ of graphite). The samples were placed into the mass spectrometer until the pressure of the ion source was lower than $2.5 \times 10^{-7}$ mbars. The $\delta^{37} \mathrm{Cl}$ values of the water samples from springs were calculated as follows. The reported $\delta^{37} \mathrm{Cl}$ values are plotted relative to the Standard Mean Ocean Chloride (SMOC). The average $\left({ }^{37} \mathrm{Cl} /{ }^{35} \mathrm{Cl}\right)$ smoc was $0.318990 \pm 0.000041(2 \sigma, n=6)$, which is in agreement with the certified value of Xiao. The expressions for $\delta^{11} \mathrm{~B}$ and $\delta^{37} \mathrm{Cl}$ are shown below [72,73].

$$
\begin{gathered}
\boldsymbol{\delta}^{11} \mathbf{B}(\%)=\left[\left({ }^{11} \mathbf{B} /{ }^{10} \mathbf{B}\right)_{\text {sample }} /\left({ }^{11} \mathbf{B} /{ }^{10} \mathbf{B}\right)_{\text {standard }}-1\right] \times 10^{3} \\
\mathcal{\delta}^{37} \mathbf{C l}(\%)=\left[\left({ }^{37} \mathrm{Cl} /{ }^{35} \mathbf{C l}\right)_{\text {sample }} /\left({ }^{37} \mathbf{C l} /{ }^{35} \mathbf{C l}\right)_{\text {standard }}-1\right] \times 10^{3}
\end{gathered}
$$




\section{Results}

Tables 1 and 2 show the results of the chemical and isotopic analyses of the saline spring water samples from north and central Laos. The saline springs in this study have total dissolved solids (TDS) of $11.65-311.27 \mathrm{~g} / \mathrm{L}$ and a $\mathrm{pH}$ of 6.85 to 7.60 . The outlet temperatures of the saline springs range from $8.5{ }^{\circ} \mathrm{C}$ to $14{ }^{\circ} \mathrm{C}$. The values of the stable isotopes of the water $\left(\delta \mathrm{D}\right.$ and $\left.\delta^{18} \mathrm{O}\right)$ range from -101.0 to $-42.5 \%$ and from -12.3 to $-6.1 \%$ V-SMOW, respectively (Table 2). The halite leached brines are greatly influenced by the isotopic composition [74]. The saline springs in this study vary from 5.5 to $36.0 \%$ and from -0.12 to $0.79 \%$, respectively, for the stable isotope $\delta^{11} \mathrm{~B}$ and $\delta^{37} \mathrm{Cl}$ values.

Table 1. Hydrochemical composition of salty groundwater and brines from springs in northern and central Laos.

\begin{tabular}{|c|c|c|c|c|c|c|c|c|c|c|c|c|c|c|c|}
\hline Samples & $\begin{array}{c}\text { Sample } \\
\text { Type }\end{array}$ & TDS & $\mathrm{Na}^{+}$ & $\mathrm{Ca}^{2+}$ & $\mathrm{Mg}^{2+}$ & $\mathbf{K}^{+}$ & $\mathrm{Li}^{+}$ & $\mathrm{Sr}^{2+}$ & B & Si & $\mathrm{Cl}^{-}$ & $\mathrm{HCO}_{3}{ }^{-}$ & $\mathrm{SO}_{4}^{2-}$ & $\mathbf{F}^{-}$ & $\mathrm{Br}^{-}$ \\
\hline & & \multicolumn{4}{|c|}{$\mathrm{g} / \mathrm{L}$} & \multicolumn{5}{|c|}{$\mathrm{mg} / \mathrm{L}$} & \multicolumn{3}{|c|}{$\mathrm{g} / \mathrm{L}$} & \multicolumn{2}{|c|}{$\mathrm{mg} / \mathrm{L}$} \\
\hline $\begin{array}{l}\text { Muang } \\
\text { Ou Tai }\end{array}$ & Brine & 85.83 & 31.75 & 1.26 & 0.14 & 355.50 & 2.65 & 16.93 & 1.04 & 15.61 & 49.13 & 0.24 & 3.12 & 1.86 & 21.99 \\
\hline $\begin{array}{c}\text { West } \\
\text { Moding }\end{array}$ & Brine & 311.27 & 116.55 & 1.69 & 0.37 & 867.00 & 3.55 & 31.73 & 14.07 & 17.12 & 185.54 & 0.04 & 3.64 & & 62.95 \\
\hline $\begin{array}{l}\text { Mankuang } \\
\text { saltworks }\end{array}$ & Brine & 288.92 & 109.25 & 1.64 & 0.11 & 780.50 & 3.08 & 21.43 & 1.39 & 51.18 & 172.86 & 0.08 & 2.49 & & 45.09 \\
\hline $\begin{array}{c}\text { East } \\
\text { Muang } \\
\text { Say }\end{array}$ & $\begin{array}{c}\text { Salty } \\
\text { water }\end{array}$ & 11.65 & 3.61 & 0.56 & 0.05 & 152.02 & 2.67 & 14.41 & 1.30 & 23.43 & 6.37 & 0.35 & 0.45 & 0.18 & 2.04 \\
\hline $\begin{array}{c}\text { South } \\
\text { Pak-Lay }\end{array}$ & Brine & 152.58 & 57.53 & 1.74 & 0.34 & 569.25 & 2.23 & 33.08 & 1.04 & 21.85 & 90.98 & 0.20 & 1.73 & 0.64 & 50.18 \\
\hline $\begin{array}{l}\text { Muang } \\
\text { Say 01 }\end{array}$ & $\begin{array}{l}\text { Salty } \\
\text { water }\end{array}$ & 12.06 & 3.68 & 0.63 & 0.06 & 133.35 & 2.60 & 15.60 & 1.30 & 24.79 & 6.70 & 0.24 & 0.53 & & 1.72 \\
\hline $\begin{array}{l}\text { Muang } \\
\text { Say 02 }\end{array}$ & $\begin{array}{c}\text { Salty } \\
\text { water }\end{array}$ & 12.62 & 3.83 & 0.67 & 0.06 & 162.00 & 2.33 & 16.96 & 1.39 & 25.76 & 7.01 & 0.33 & 0.46 & & 1.60 \\
\hline Thakhek & Brine & 76.49 & 26.46 & 2.11 & 0.38 & 323.80 & 0.51 & 11.44 & 3.12 & 33.67 & 42.61 & 0.07 & 4.48 & & 19.35 \\
\hline
\end{tabular}

Table 2. Field observations, locations, water types, and isotope date of the saline springs in north and central Laos.

\begin{tabular}{|c|c|c|c|c|c|c|c|c|c|c|}
\hline $\begin{array}{c}\text { Sample } \\
\text { Name }\end{array}$ & Location & $\begin{array}{l}\text { Elevation } \\
\text { (m) }\end{array}$ & $\begin{array}{l}\text { Water } \\
\text { Type }\end{array}$ & $\mathrm{T}\left({ }^{\circ} \mathrm{C}\right)$ & $\mathrm{pH}$ & $\delta \mathrm{D}_{\mathrm{V}-\mathrm{SMOW}}$ & $\delta^{18} \mathrm{O}_{\mathrm{V}-\mathrm{SMOW}}$ & d Value & $\delta^{11} B$ & $\delta^{37} \mathrm{Cl}$ \\
\hline $\begin{array}{l}\text { Muang } \\
\text { Ou Tai }\end{array}$ & $\begin{array}{c}\mathrm{N} \\
22^{\circ} 08^{\prime} 30.0^{\prime \prime} \\
\mathrm{E} 101^{\circ}\end{array}$ & 718 & $\mathrm{NaCl}$ & 9.5 & 6.94 & -76.14 & -9.03 & -3.90 & 20.29 & 0.14 \\
\hline $\begin{array}{l}\text { West } \\
\text { Moding }\end{array}$ & $\begin{array}{c}\mathrm{N} \\
21^{\circ} 08^{\prime} 48.0^{\prime \prime} \\
\mathrm{E} 101^{\circ}\end{array}$ & 798 & $\mathrm{Na}-\mathrm{Cl}$ & 11.0 & 6.85 & -100.97 & -12.28 & -2.73 & 36.01 & 0.79 \\
\hline $\begin{array}{l}\text { Mankuang } \\
\text { saltworks }\end{array}$ & $\begin{array}{c}\mathrm{N} \\
21^{\circ} 03^{\prime} 42.9^{\prime \prime} \\
\mathrm{E} 101^{\circ}\end{array}$ & 807 & $\mathrm{Na}-\mathrm{Cl}$ & 10.5 & 6.90 & -82.98 & -9.88 & -3.94 & 24.10 & -0.12 \\
\hline $\begin{array}{c}\text { East } \\
\text { Muang } \\
\text { Say }\end{array}$ & $\begin{array}{c}\mathrm{N} \\
20^{\circ} 52^{\prime} 08.0^{\prime \prime} \\
\mathrm{E} 102^{\circ}\end{array}$ & 456 & $\mathrm{Na}-\mathrm{Cl}$ & 10.5 & 7.00 & -78.34 & -8.15 & -13.14 & 5.50 & 0.54 \\
\hline $\begin{array}{c}\text { South } \\
\text { Pak-Lay }\end{array}$ & $\begin{array}{c}\mathrm{N} \\
17^{\circ} 36^{\prime} 20.9^{\prime \prime} \\
\mathrm{E} 101^{\circ}\end{array}$ & 319 & $\mathrm{Na}-\mathrm{Cl}$ & 8.5 & 7.02 & -67.85 & -6.53 & -15.61 & 33.33 & \\
\hline $\begin{array}{l}\text { Muang } \\
\text { Say 01 }\end{array}$ & $\begin{array}{c}\mathrm{N} \\
20^{\circ} 52^{\prime} 06.0^{\prime \prime} \\
\text { E } 098^{\circ}\end{array}$ & 427 & $\mathrm{Na}-\mathrm{Cl}$ & 12.1 & 7.60 & -56.40 & -7.80 & 6.00 & 8.08 & \\
\hline $\begin{array}{l}\text { Muang } \\
\text { Say 02 }\end{array}$ & $\begin{array}{c}\mathrm{N} \\
20^{\circ} 52^{\prime} 06.0^{\prime \prime} \\
\text { E } 098^{\circ}\end{array}$ & 416 & $\mathrm{Na}-\mathrm{Cl}$ & 11.7 & 7.40 & -50.30 & -7.90 & 12.90 & 6.77 & \\
\hline Thakhek & $\begin{array}{c}\mathrm{N} \\
17^{\circ} 24^{\prime} 40.4^{\prime \prime} \\
\mathrm{E} 104^{\circ}\end{array}$ & 127 & $\mathrm{Na}-\mathrm{Cl}$ & 14.0 & 7.20 & -42.50 & -6.10 & 6.30 & 17.05 & \\
\hline
\end{tabular}




\section{Discussion}

\subsection{Origin of the Water Molecules}

The $\delta^{18} \mathrm{O}$ versus $\delta \mathrm{D}$ for saline springs from southwestern China and Laos and comparison with the global meteoric water line (GMWL) [11], southeast Asia meteoric water line (RMWL) [75], and southwest Chinese meteoric water line (SW CMWL) are plotted in Figure 3. All the saline spring water samples in the study area and Yunnan of China were slightly below and near the meteoric water line, which indicates they were from local precipitation. The hydrogen and oxygen isotope values of atmospheric origin decrease in the groundwater with an increase in recharge elevation, which can be used to estimate the recharge elevation of atmospheric origin [76,77].

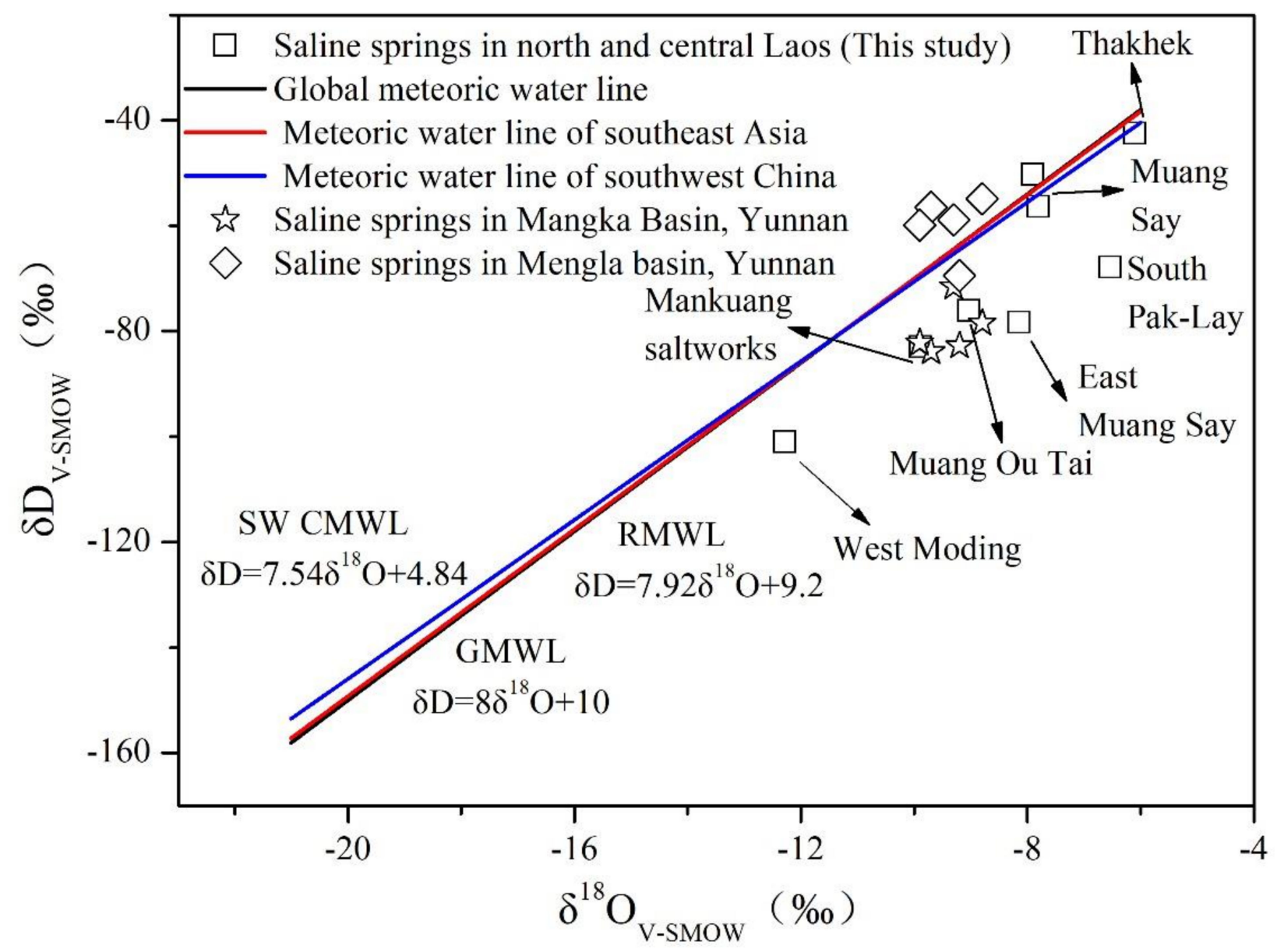

Figure 3. Isotope composition $\left(\delta \mathrm{D}\right.$ and $\left.\delta^{18} \mathrm{O}\right)$ of the saline springs in north and central Laos plotted against the GMWL, the SW CMWL, and the RMWL, the comparison area date from $[67,78]$.

The $\delta \mathrm{D}$ values are relatively stable during high-temperature hydrolithogenesis due to the low hydrogen content in the rock minerals, and the recharge altitudes and their average values are therefore based on the $\delta \mathrm{D}$ values. As the study area is adjacent to the southwest China, the recharge elevations $(\mathrm{H})$ were estimated by the formula $\delta \mathrm{D}=-0.026 \mathrm{H}-30.2$, which applies to southwest China and its surrounding areas [77]. The mean recharge elevations of the saline spring waters in north and central Laos $(1508 \mathrm{~m})$ are close to the mean altitudes of the surrounding mountains (Phu Bia, Phu Lay, Lao Bi, and Phu Miyang), which are above $1500 \mathrm{~m}$. The estimated recharge elevation of the saline springs in this study ranged from $473.9 .9 \mathrm{~m}$ to $2722 \mathrm{~m}$, which are $346.1-\mathrm{m}$ to $1924-\mathrm{m}$ higher than the sampling elevation (at 127-807 m). This means that the vertical water head difference between the spring recharge area and the discharge area is large, which may be an important factor in driving the rapid and deep circulation of spring waters under the action of gravity. 
Generally, river and lake water does not infiltrate deep geothermal reservoirs under the action of gravity. It can therefore be assumed that the main recharge sources for the saline springs from north and central Laos are likely to be rainfall and/or ice or snow melt from the surrounding mountains. Moreover, the flow rate of the recharge source will increase with increasing hydraulic gradient. The deep and large-scale faults and small-scale faults that were caused by plate collision can however provide migration channels for the deep circulation of saline springs, such as is the case with the Dien Bien Phu fault.

\subsection{Solute Sources and Genesis of Spring Waters \\ 5.2.1. Hydrochemistry Evidence}

The saline springs can be classified as $\mathrm{Na}-\mathrm{Cl}$ (based on the Schukalev and Kurllov classification) or as a chloride type (based on the Valyashko classification), respectively [74]. $\mathrm{Cl}$ and $\mathrm{Na}$ are the major constituents that generate the overall salinity of the springs. The saline springs all have similar chemical characteristics, with $\mathrm{Na}+\mathrm{K}>\mathrm{Ca}>\mathrm{Mg}$ and $\mathrm{Cl}>\mathrm{SO}_{4}>\mathrm{HCO}_{3}$. The classical Gibbs diagram (Figure 4) shows that the saline springs' chemical composition is dominated by evaporation crystallization processes because all the data points plot on the evaporation crystallization end member, similar to the composition of seawater, saline springs, and underground brines in Laos, Thailand, and southwestern Yunnan, China. Halite and potash deposits in Laos are mainly originated from the Cretaceous seawater, with subordinate continental water and possible hydrothermal supplies, there have been cases of flooding by the sea of the Laos territory over the past 145 million years. The halite strata were formed by evaporation from the seawater, which was probably derived from Tethys ocean. These brines also existed during the formation of halite, and residual water flowed into Thailand in subsequent periods. Therefore, the composition of spring water sources is the result of dilution of sea waters and brines by atmospheric precipitation. The rock (evaporites) -water (atmospheric precipitation) interactions and dilution of sea waters are two important factors that controls the chemical composition of saline springs.

The conservative elements $(\mathrm{Cl}$ and $\mathrm{Br})$ and the seawater evaporation trajectories (SET) are frequently used to explain the origin and evolution of brines $[79,80]$. The $\mathrm{Cl} / \mathrm{Na}$, $\mathrm{Cl} / \mathrm{K}, \mathrm{Cl} / \mathrm{Mg}, \mathrm{Cl} / \mathrm{Li}, \mathrm{Br} / \mathrm{Ca}, \mathrm{Br} / \mathrm{K}$, and $\mathrm{Br} / \mathrm{Cl}$ of saline springs and underground brines are therefore plotted onto the SET (see Figure 5). The $\mathrm{Na} / \mathrm{Cl}$ ratios consistently plot above the SET from Figure 5a, with an approximate 1:1 molar ratio. This means that saline springs originate from the dissolution of halite and typically generate $\mathrm{Cl}$-rich brines with a high $(\approx 1: 1) \mathrm{Na}: \mathrm{Cl}$ molar ratio [80]. The $\mathrm{K}$ concentrations of saline springs in this study are depleted relative to $\mathrm{Cl}$ but enriched relative to $\mathrm{Br}$ (except for Muang Say), and the ratios of $\mathrm{K} / \mathrm{Br}$ and $\mathrm{K} / \mathrm{Cl}$ are consistent with the SET. Of the $\mathrm{K}$ concentrations of the underground brines in the potash mining area, the Thakhek is higher than the peak of the SET (representing the precipitation stage of potash minerals) in the log plot of $\mathrm{Cl} / \mathrm{K}, \mathrm{Br} / \mathrm{K}, \mathrm{Cl} / \mathrm{Br}$, and $\mathrm{Cl} / \mathrm{B}$ (see Figure 5 ). The $\mathrm{K}^{+}$concentrations of saline springs in Muang Say are however a deviation from the SET. The partial dissolution of halite and sylvite may have impacted the $\mathrm{K}$ content in the saline springs, while the $\mathrm{K}$ content in the underground brine comes entirely from the leaching of carnallite and sylvite [66]. According to Cerling et al. [81], $\mathrm{Na}$ ions released from clay minerals can be used as exchange ions in cases where the clay minerals are weathered by meteoric water, whereas the adsorption of clay minerals result in $\mathrm{Mg}$ depletion. In the saline springs from the study area, $\mathrm{Ca}$ is enriched relative to $\mathrm{Cl}$ and $\mathrm{Br}$. The dissolution of $\mathrm{Ca}$-bearing minerals $\left(\mathrm{CaSO}_{4}, \mathrm{CaCO}_{3}\right.$, and $\left.\mathrm{CaMg}\left(\mathrm{CO}_{3}\right)_{2}\right)$ and the ankeritization of dolomite and calcite in the study area could explain the excess $\mathrm{Ca}$ in the saline springs. $\mathrm{Mg}$ is depleted relative to $\mathrm{Cl}$, which means that the adsorption of clay minerals in the saline springs is stronger than the dissolution of $\mathrm{Mg}$ minerals $\left(\mathrm{CaMg}\left(\mathrm{CO}_{3}\right)_{2}\right.$ and $\left.\mathrm{MgCO}_{3}\right)$. Li does not contribute to diagenesis, and it is enriched in authigenic magnesites and $\mathrm{Li}$-bearing silicates. The enrichment of Li relative to $\mathrm{Cl}$ can contribute to the dissolution of authigenic magnesites, which are widely distributed in the salt-bearing clastic layer of the study area. $\mathrm{Li}^{+}$concentrations of 
underground brine in the potash mining area in central Laos are however lower than the peak of the precipitation stage of the sylvite, which indicates that no Li-bearing minerals are found in the mining area [82]. The SET is constant until halite saturation during seawater evaporation and waters derived from halite dissolution and mixed with marine and meteoric waters experience the enrichment of $\mathrm{Cl}$ relative to $\mathrm{Br}$ and plot beneath the SET [83]. Therefore, saline springs in this study that plot above and along with the SET (Figure $5 \mathrm{~g}$ ) are likely dominated by meteoric mixtures and halite dissolution. Based on the above, (1) halite dissolution should be a major solute source, (2) the dissolution of sulfate and carbonate rocks may be a minor solute source for saline springs in north and central Laos, and (3) underground brines in the potash mining area, central Laos, are geochemically influenced by the dissolution of carnallite and sylvite. These conclusions are supported by saliferous lithologies in north and central Laos.
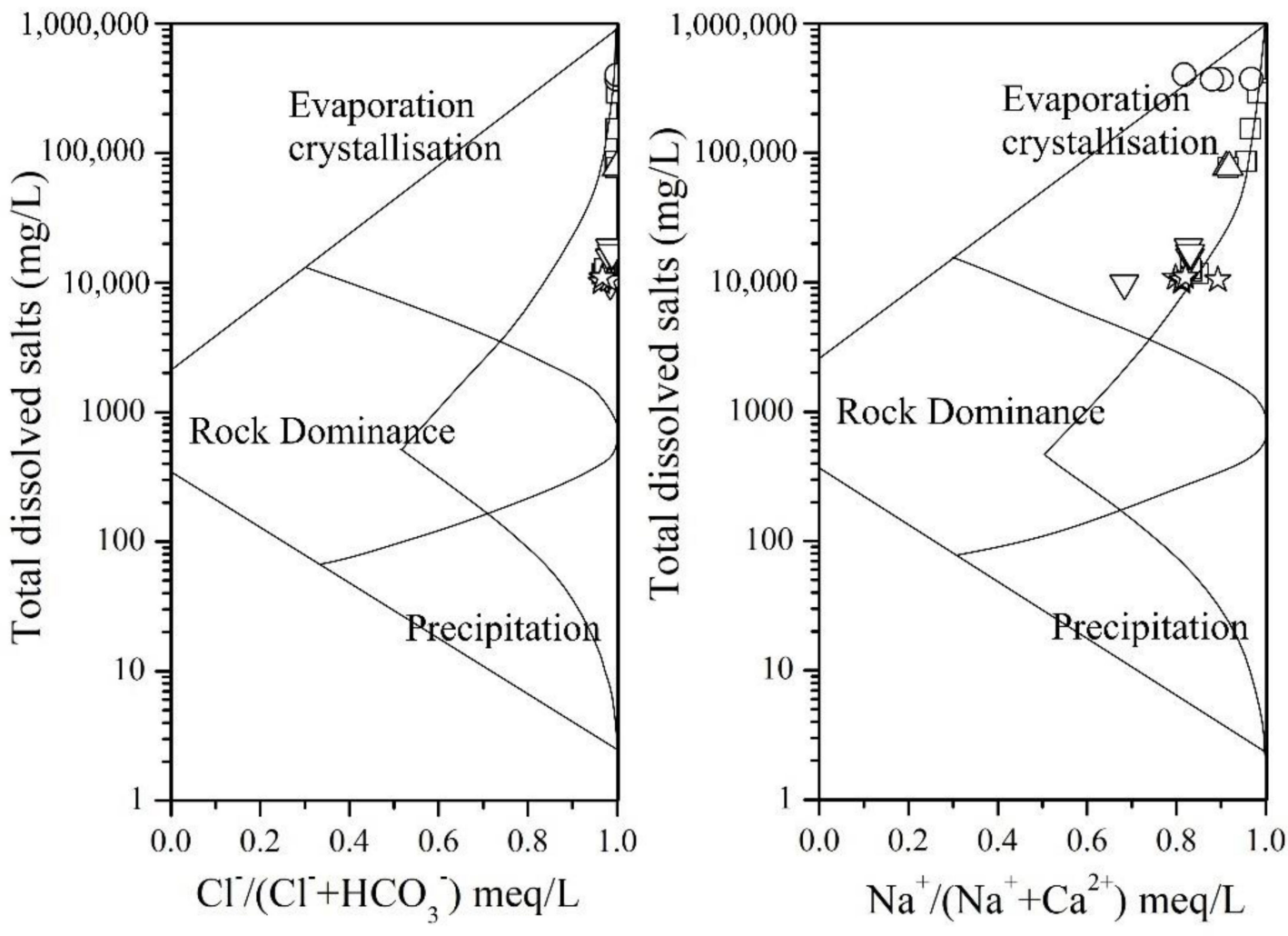

$\square$ Saline springs in north and central Laos (This study)

$\bigcirc$ Underground brines in potash mining area, central Laos

$\triangle$ Saline springs in potash mining area, central Laos

$\nabla$ Hot saline springs in Krabi, Thailand

is Saline springs in Mangka basin, southwestern Yunnan

Figure 4. Gibbs diagram of the saline springs in north and central Laos, the comparison area date from $[66,67,69]$. 

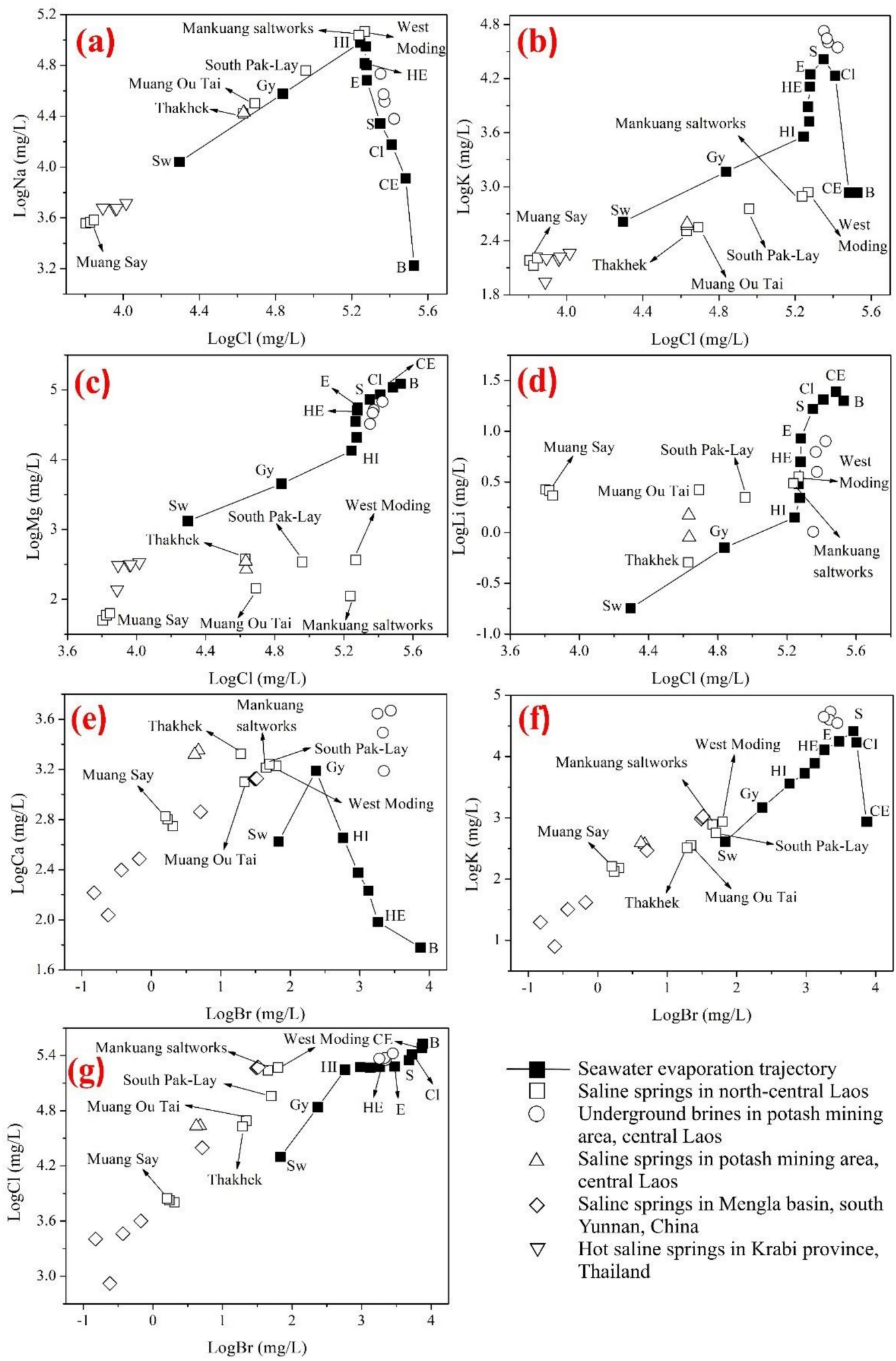

Figure 5. Plot of $\mathrm{Cl}$ vs. $\mathrm{Na}(\mathbf{a}), \mathrm{Cl}$ vs. $\mathrm{K}(\mathbf{b}), \mathrm{Cl}$ vs. $\mathrm{Mg}$ (c), $\mathrm{Cl}$ vs. $\mathrm{Li}(\mathbf{d}), \mathrm{Br}$ vs. $\mathrm{Ca}(\mathbf{e}), \mathrm{Br}$ vs. $\mathrm{K}$ (f), and $\mathrm{Br}$ vs. $\mathrm{Cl}$ (g); $\mathrm{SET}$, HDL, Sw, Gy, HI, HE, E, S, CI, CE, and B represent seawater evaporation trajectory [80], halite dissolution line [84], seawater, gypsum precipitation point, halite precipitation initial point, halite precipitation end point, epsomite precipitation point, sylvite precipitation point, carnallite precipitation initial point, carnallite precipitation end point, and bischofite precipitation point [80], respectively. Date of underground brines and saline springs in potash mining area, central Laos from [66], saline springs in Yunan from [85], and hot saline springs in Thailand from [69]. 
The ternary $\mathrm{Ca}-\mathrm{SO}_{4}-\mathrm{HCO}_{3}$ phase diagram (Figure 6a) reflects the evolution of the surface fluid chemical composition. Water samples from the saline springs in the study area fall into the $\mathrm{Cl}-\mathrm{SO}_{4}$ field, which may be related to the dissolution and recycling of buried gypsum/anhydrite in saliferous strata from north and central Laos [86,87]. This may be the main reason for the lack of alkaline $\mathrm{HCO}_{3}-\mathrm{CO}_{3}$-rich saline springs in north and central Laos. Deep $\mathrm{Ca}-\mathrm{Cl}$ brines are formed by the interaction of the diagenetic or hydrothermal water with rocks and sediments at high temperatures and deep circulation and return to the surface along faults [88]. If groundwater falls into the $\mathrm{Ca}-\mathrm{Cl}$ field, this means that the water is mainly influenced by deep Ca-Cl-type waters. Most of the hot saline springs in Krabi province, Thailand, mainly recharge from deep Ca-Cl-type waters that are mixed with meteoric water. Deep Ca-Cl-type waters and the dissolution of sylvite/carnallite may be the main source of solutes in the underground brines from the Longhu potash mining area in Khammouane Province, Central Laos. Additionally, the $\delta^{11} \mathrm{~B}$ data $(+19.8 \sim+21.0 \%)$ of these underground brines are near those of evaporites (carnallite and sylvite), suggesting that dissolution of carnallite and sylvite by surface water is the major boron origin of these underground brines [66]. Based on the above analyses, the dissolution of halite may be viewed as the main solute source, with the dissolution of marine gypsum/anhydrite and carbonatites being a relatively minor source in saline springs in the study area.

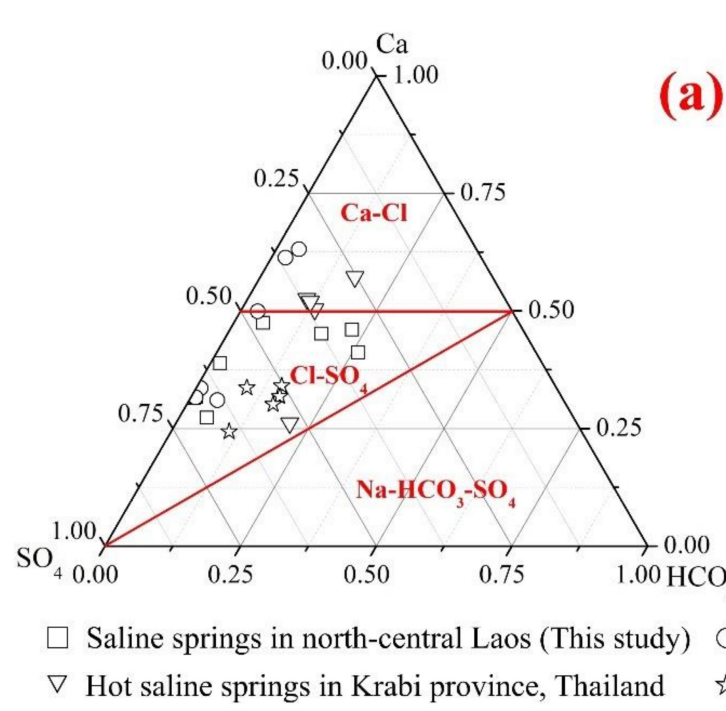

Figure 6. (a). Ternary $\mathrm{Ca}-\mathrm{SO}_{4}-\mathrm{HCO}_{3}$ phase diagram of saline springs from north and central Laos; (b). Na-K-Mg ternary diagram showing saline springs from north and central Laos. Date from $[66,69,85]$.

\subsubsection{Evidence-Based on Saturation Index (SI)}

The saturation index (SI) of the groundwater is a reflection of the degree of waterrock/mineral reaction. The SI values of the saline springs from north and central Laos were calculated by PHREEQC with temperature. As shown by the trend of mineral saturation (Figure 7a), all saline spring water samples are saturated with aragonite, calcite, dolomite, and talc (and have SI values averaging 1.2, 1.3, 1.8, and 8.5, respectively). These SIs indicate the deposition of carbonate minerals. An oversaturation of any element would lead to the precipitation of that element. The oversaturation of $\mathrm{Ca}^{2+}$ and $\mathrm{Ca}^{2+}+\mathrm{Mg}^{2+}$ is explained by the presence of dolomite and limestone in the Jurassic to Cretaceous sediments in the study area. Only the saline spring water samples of West Moding, the Mankuang saltworks, and Thakhek are saturated in gypsum, while all the saline spring water samples are saturated in anhydrite, except for samples from Muang Say. This means that sulfate minerals in the saline springs of Muang Say are still in the dissolution stage, while those of West Moding, the Mankuang saltworks, and Thakhek are in the deposition stage. Apart from the halite SI being saturated for West Moding $(\approx 0)$, the halite SI for the rest of the saline springs is far 
from saturated, indicating that the saline spring waters in the study area are in the halite dissolution stage. The SI values of the carbonate minerals (calcite, aragonite, and dolomite) are independent of TDS, while those of the sulfate minerals (anhydrite and gypsum) and halite tend to increase with an increase in TDS $\left(\mathrm{R}^{2}=0.87\right)$ (Figure $\left.7 \mathrm{~b}\right)$, suggesting that the dissolution of halite and gypsum could be the main driver for the increase of salinity. This theory is confirmed by the extensive occurrence of late Cretaceous salt-bearing strata in the study area.
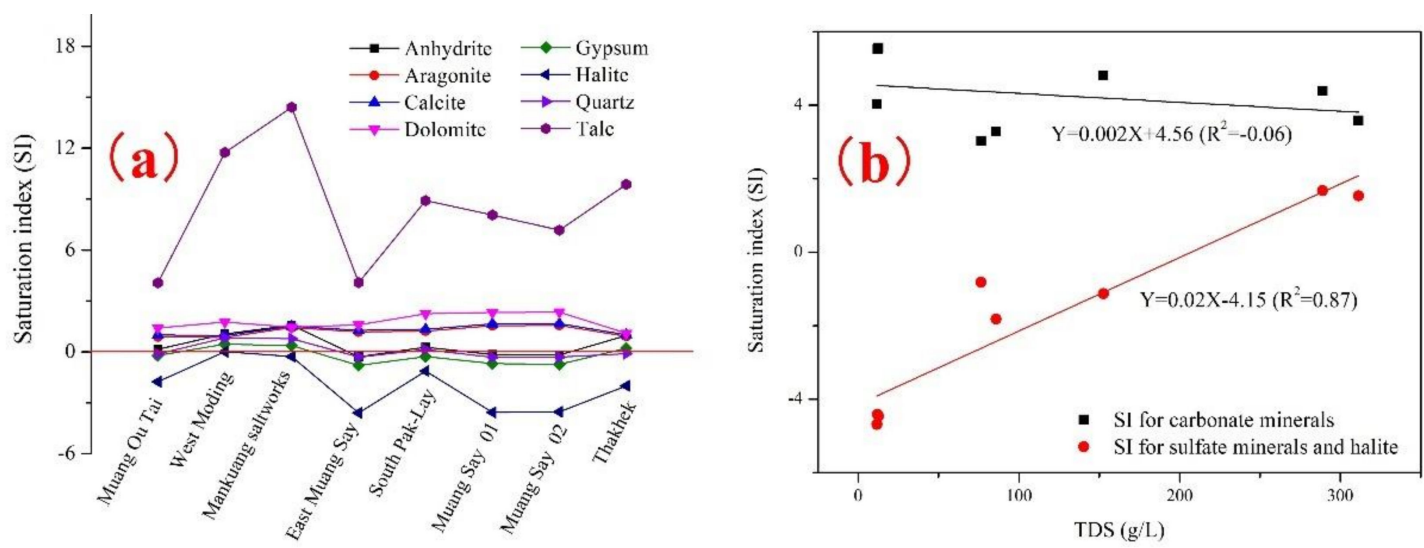

Figure 7. (a). Plot of the saturation indexes of saline spring water samples from north and central Laos. (b). Plot of TDS vs. saturation indexes (SI) of saline spring water samples from north and central Laos.

\subsubsection{Inference from Boron Isotopes}

In this study, there is no obvious linear relationship $\left(R^{2}=0.35\right)$ between the $\delta^{11} \mathrm{~B}$ value and the $\mathrm{pH}$ (Figure $8 \mathrm{a}$ ), and the $\mathrm{pH}$ of saline springs is therefore not the main factor influencing the $\delta^{11} \mathrm{~B}$ value, which may be controlled by its source area. We can therefore determine the solute source of the saline springs based on the $\delta^{11} \mathrm{~B}$ characteristics. There are three important salt-bearing basins in north and central Laos: the Muong Say, the Vientiane, and the Khammouane Basin, with the late Cretaceous evaporites, clastic deposits, and continental red beds being widely distributed in north and central Laos [2-4]. Carbonates and crustal-derived volcanics from Jurassic to Paleogene are also present in the study area. The characteristics of boron isotopes can be used to distinguish between marine and non-marine sedimentary environments. The $\delta^{11} \mathrm{~B}$ value of saline springs (5.50 to $36.01 \%$, average $=18.89 \%$ ) in this study is lower than that of the present-day seawater (36.36 to $45.75 \%$ ) [89-91], which differs significantly from continental evaporates (-6.83\%o to $-5.79 \%$ ). The $\delta^{11} \mathrm{~B}$ value of saline springs is however very close to that of salts that have precipitated from evapo-concentrated seawater $(10 \%$ to $36 \%$ ) as well as marine carbonates $(-5.5 \%$ to $23 \%$ ) (see Figure $8 b$,c). These data, therefore, support a continental origin for the boron in the saline springs [89,92]. This boron is most likely derived from marine carbonates/salts and crustal-derived volcanics.

The positive correlation between the $\mathrm{Cl} / \mathrm{B}$ ratios and the $\delta^{11} \mathrm{~B}$ values in the brines and the paleoevaporites worldwide makes it possible to effectively distinguish between marine and terrestrial sources $[93,94]$. Marine sources are located at the high $\delta^{11} \mathrm{~B}$ and high $\mathrm{Cl} / \mathrm{B}$ end member, while terrestrial sources are characterized by lower $\delta^{11} \mathrm{~B}$ and lower $\mathrm{Cl} / \mathrm{B}$ ratios [95]. We compared our data to that of geothermal systems worldwide and found binary mixing between a continental end member and a marine end member (Figure 9). The hot springs in India, the Dead Sea (Israel), the Izu Peninsula (central Japan), and northeastern Taiwan are all strongly influenced by seawater, which is enriched in ${ }^{11} \mathrm{~B}$. The $\delta^{11} \mathrm{~B}$ values in these marine springs are all higher than the saline springs in our study area, which means that saline springs in our study are of terrestrial origin [28,96-98]. Several factors influence the distribution and relationships of $\delta^{11} \mathrm{~B}-\mathrm{Cl} / \mathrm{B}$ in non-marine springs around the world, including the rock type, the presentence of any tectonic structures, and the geological setting. The $\delta^{11} \mathrm{~B}$ value of geothermal waters may indicate different $\mathrm{B}$ 
sources (for example, a mantle source for Iceland and the Ngawha geothermal system in New Zealand, magmatic rocks for the Taupo Volcanic Zone in New Zealand [99-101] and the Yellowstone National Park [100,102], groundwater mixing for Java in Indonesia [103], and a granitic source for the Limagne Basin in France [104]). The $\delta^{11} \mathrm{~B}$ values of the springs in the marine carbonates $(+10 \%$ to $+30 \%$ o $)[21,105]$ and halite/potash-associated minerals of the Khammouane potash deposit $(19.91 \%$ to $31.01 \%$ o $)$ [7] differs significantly from the continental evaporates $(-6.83 \%$ to $-5.79 \%)$, the primitive mantle $(-12 \%$ o to $-8 \%$ ), springs in metamorphic rocks $(-9.0 \%$ to $-7.4 \%$ ), and igneous rocks $(-17 \%$ to $-2 \%$ ) $[94,106,107]$ but is very close to that of the saline springs in this study area. The $\delta^{11} \mathrm{~B}$ values show that marine carbonate rocks and marine evaporites (gypsum and halite) are the main sources of boron in the saline springs from north and central Laos and are similar to the saline springs of the Nangqen-Qamdo-Simao Salt Basin $[108,109]$. The higher $\mathrm{Cl} / \mathrm{B}$ ratios are caused by the dissolution of salt in the saline springs of the study area, which exceed those of other global geothermal systems. The B in thermal waters of the Qamdo-Simao Salt Basin and the Tibet Geothermal Belt is mainly controlled by marine carbonate rocks and B-enriched volcanic rocks, while the springs in the western Yunnan geothermal belt also differs from the B sources of the saline springs in this study [107]. The $\mathrm{B}$ in the springs from the western Yunnan geothermal belt has both crustal and mantle sources and is mainly controlled by the leaching of reservoir host rocks (large granitic batholiths and metamorphic rocks) and by magmatic fluids from shallow magma $[107,110]$.

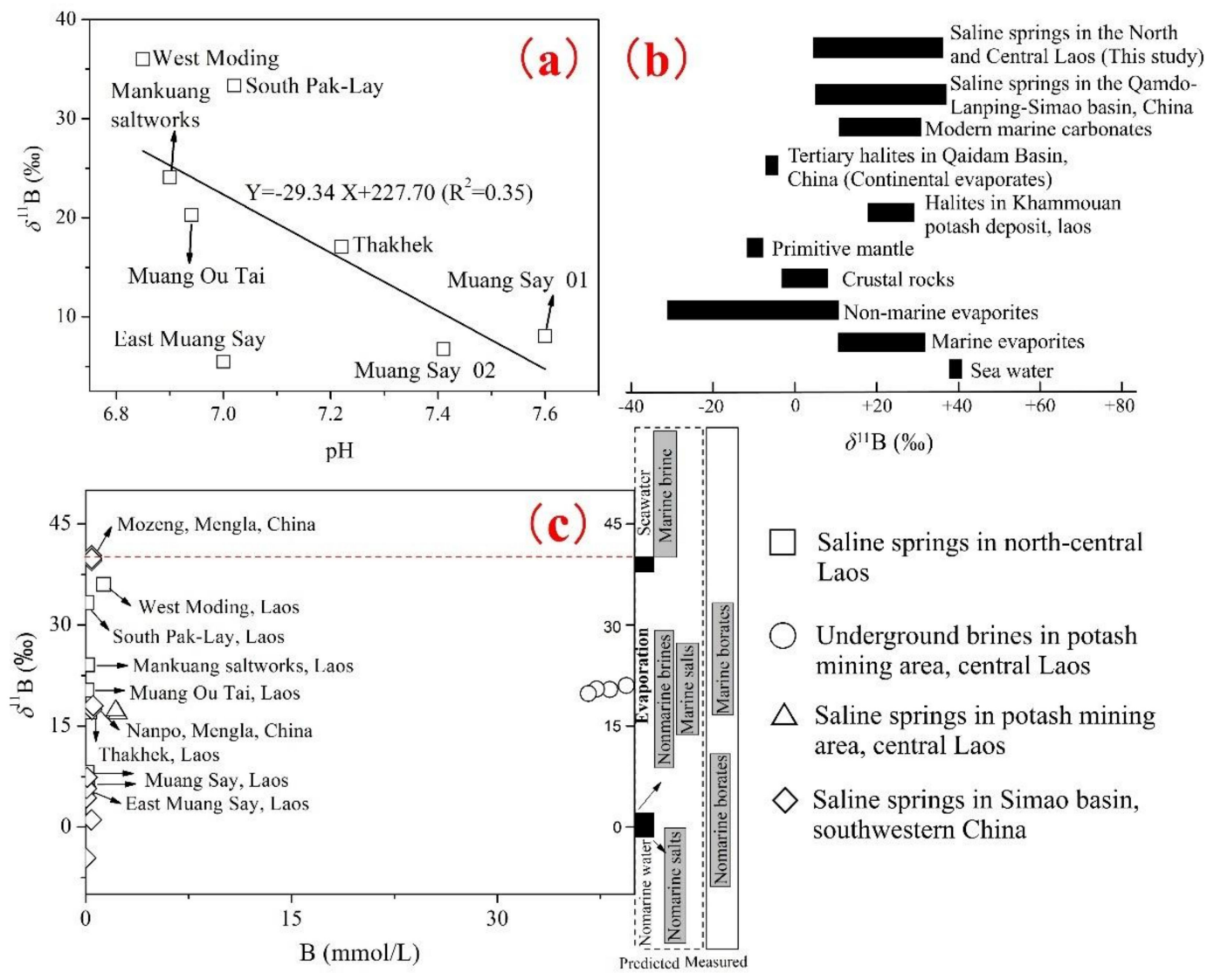

Figure 8. (a). $\mathrm{pH}$ vs. $\delta^{11} \mathrm{~B}$ of saline springs from north and central Laos; (b). Range of $\delta^{11} \mathrm{~B}$ values from different boron sources $[7,79,106,111] ;$ (c). $\delta^{11} \mathrm{~B}$ vs. B of saline springs and underground brines from the southwestern China and north and central Laos compared with the predicted $\delta^{11} \mathrm{~B}$ values based on experimental and measured $\delta^{11} \mathrm{~B}$ values in natural systems of marine salts, marine brines, nonmarine salts, and nonmarine brines [93,94]. 


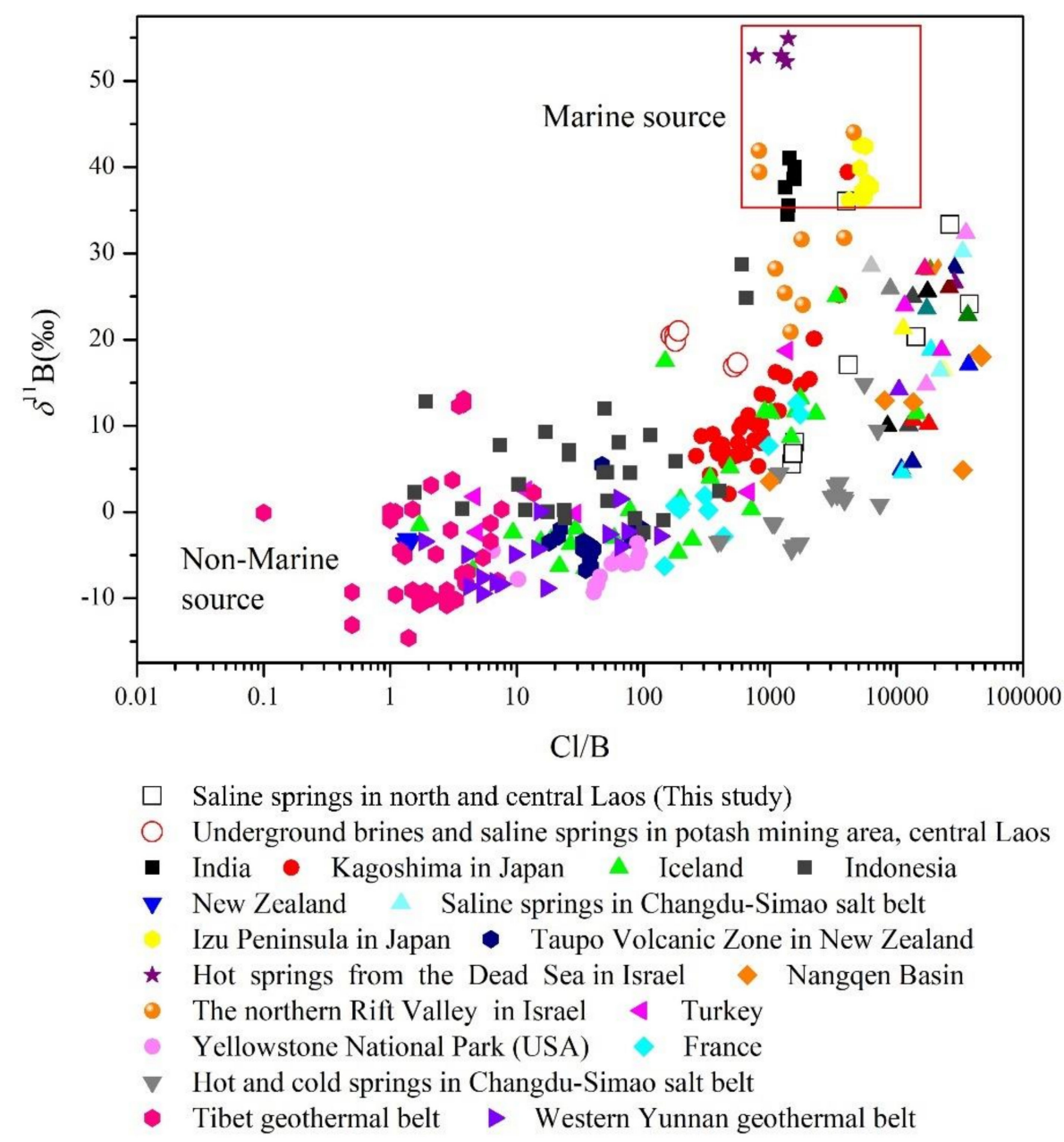

Figure 9. Correlations between $\delta^{11} \mathrm{~B}-\mathrm{Cl} / \mathrm{B}$ for springs of major geothermal systems around the world.

\subsubsection{Inference from Chlorine Isotopes}

Stable chlorine isotopes $\left(\delta^{37} \mathrm{Cl}\right)$ can be used to study dissolved $\mathrm{Cl}$, fluid mixing, waterrock interactions [47,112], and evaporation rates in the salt lake systems [73,113-115]. Chlorine isotope fractionation occurs during evaporation and salt deposition, resulting in ${ }^{37} \mathrm{Cl}$ enrichment within the salt deposits and ${ }^{37} \mathrm{Cl}$ loss in residual brines [116]. Figure 5 shows the characteristics of the $\mathrm{Cl}$ isotope for different fluids and saline minerals. In this study, the saturation index of halite $(\mathrm{NaCl})$ in saline springs is less than 0 , except for West Moding, which is about 0 . There is no correlation between the $\delta^{37} \mathrm{Cl}$ values and the $\mathrm{Cl}$ concentrations, indicating that the isotopic composition of chlorine is not controlled by halite precipitation, where halite precipitation is caused by groundwater-rock interaction or by differing flowpaths. The dissolution and recrystallization of halite do not change the $\mathrm{Cl} / \mathrm{Br}$ ratio of the brine [31]; therefore, the $\delta^{37} \mathrm{Cl}$ value and the $\mathrm{Cl} / \mathrm{Br}$ ratio reflect the dissolved halite characteristics. The chloride concentration in the halite that is dissolved water is mainly controlled by the solubility of $\mathrm{NaCl}$ in the fluid, the fluid temperature, and the flow rate. By comparison, the $\mathrm{Cl} / \mathrm{Br}$ ratio of the saline springs in this study (ranging from 4076 to 9853 , with an average $=6864$ ) is within the halite characteristic value range $(>4000)$ [31,117-119]. The $\delta^{37} \mathrm{Cl}$ values of the saline springs in this study $(-0.12$ to +0.79 , average $=0.34)$ are consistent with the range of halite eigenvalues (ranging from $-1.55 \%$ to $+0.97 \%$ ) [120], which is much larger than the $\delta^{37} \mathrm{Cl}$ value of the seawater evaporation stage (see Figure 10b). This means that the saline springs are continental in origin and are possibly mainly be formed by the leaching of the underground halite layer. This interpretation of leaching from an underground halite layer is consistent with the occurrence of late Cretaceous salt-bearing strata within the study area [65]. Stable 
hydrogen and oxygen isotopes indicate that the water molecules in saline springs originate from widely distributed meteoric precipitation in north and central Laos. The $\delta^{37} \mathrm{Cl}$ values of the saline springs in this study are consistent with that of global precipitation (ranging from $-3.5 \%$ to $4.48 \%$ ) [121]. Atmospheric precipitation is therefore another factor that restricts the change of chlorine isotopes in the saline springs of the study area. Sandstone, mudstone, and volcanic rocks occur widely in the Jurassic to Paleogene strata from north and central Laos. These rocks contain large amounts of biotite and hornblende. Biotite and hornblende have higher $\mathrm{Cl} / \mathrm{Br}$ ratios and can be regarded as the most important chlorine-containing minerals in nature [122]. The $\delta^{37} \mathrm{Cl}$ compositions of biotite (ranging from $-0.26 \%$ to $3.4 \%$ ) and hornblende (ranging from $0.7 \%$ to $7 \%$ ) greatly affect the saline springs in the study area (see Figure 10a). The following conclusions can be drawn from the analysis of the $\mathrm{Cl} / \mathrm{Br}$ ratios and the $8^{37} \mathrm{Cl}$ values: (1) The dissolution of halite layers is the main solute source of brines drained by springs, (2) the water-rock interactions between volcanic rocks, mudstones, and sandstone can cause an increase in the $\mathrm{Cl} / \mathrm{Br}$ ratios and a positive shift in the $\delta^{37} \mathrm{Cl}$ values for saline springs, and (3) atmospheric precipitation can restrict the $\delta^{37} \mathrm{Cl}$ values in the saline springs.
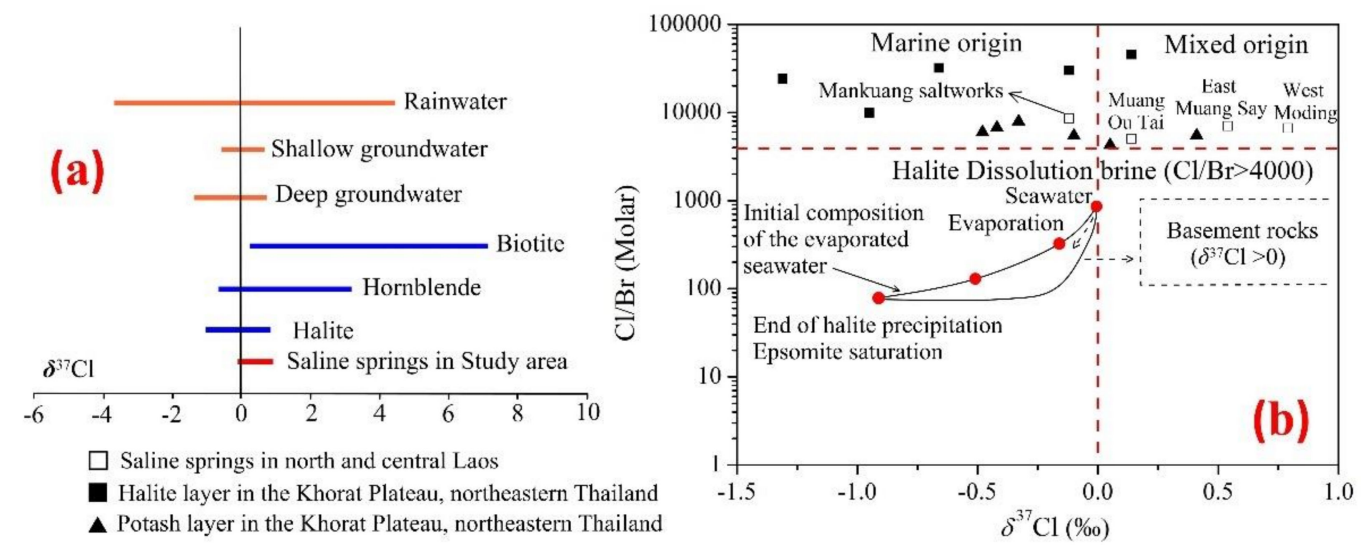

Figure 10. (a). The range of variation of $\delta^{37} \mathrm{Cl}$ in different fluids and saline minerals. Data sources: Rain water [121]; shallow and deep groundwater [123]; biotite [37]; hornblende and halite [120]. (b) Relationship between the $\mathrm{Cl} / \mathrm{Br}$ molar ratios and $\delta^{37} \mathrm{Cl}$.

\subsection{Reservoir Temperature and Circulation Depth of the Saline Springs}

Four mechanisms could explain the heat source of groundwater: (1) deep circulation of the groundwater heating the groundwater, (2) the residual heat of magma heating the groundwater, (3) friction heat from faulting heating the groundwater, and (4) the decay of radioactive elements heating the groundwater [124]. The Jurassic to Cretaceous strata are the main developed strata in the study area and are characterized by sandstone, mudstone, siltstone, limestone, dolomite, and evaporates. There are only a few magmatic rocks in the study area, which are only found sporadically in the Paleogene strata. The residual heat of magma and heat generated by the decay of radioactive elements in granite are therefore not viewed as the main heat sources of the saline springs in this study. Even though the Dien Bien Phu fault was developed in north and central Laos, the heat generated by this fault movement is insufficient to provide a sufficient heat source for the springs [124]. The saline springs in this study must therefore receive heat from heat flow during the deep circulation of groundwater. Reservoir temperature is an important parameter to evaluate the geothermal potential of geothermal fields and to classify the genetic types of geothermal systems, which can be estimated by using chemical geothermometers. Three chemical geothermometers are frequently used, including the silica geothermometer, the cation geothermometer, and the multi-mineral balance chemical geothermometer. These geothermometers are functional expressions of the solute concentration of the geothermal fluid and the reservoir temperature $[125,126]$. The different geothermometers each have 
different restrictive conditions or defects. The cation geothermometers, for example, are only applicable to the reservoir temperature calculation of full equilibrium water and include the $\mathrm{Na} / \mathrm{K}$ geothermometer, the $\mathrm{Na}-\mathrm{K}-\mathrm{Ca}$ geothermometer, and the $\mathrm{K} / \mathrm{Mg}$ geothermometer [127-130]. The Na-K-Mg ternary diagram can be used to determine the water-rock equilibrium state, the groundwater type, and the reservoir temperature as estimated by solute geothermometers [127], which shows that all the saline spring water samples in study area are all fall in the full equilibrium area (Figure 6b). Therefore, the reservoir temperatures were calculated using the silica and cation geothermometers [131], and the quartz geothermometer is most suitable for estimating the reservoir temperature (Tr) in this study.

The multi-mineral equilibrium diagram can be used to determine the chemical equilibrium between geothermal fluids and minerals. If a set of minerals in fluids approach saturation $(\mathrm{SI}=0)$ over a small temperature range, the saturation temperature is the reservoir temperature [132]. The reservoir temperature range estimated by the multi-mineral equilibrium diagram, which is also the temperature range $\left(36-173^{\circ} \mathrm{C}\right)$ for SI convergence at the zero line in Figure 11. Based on the preceding discussion, the reservoir temperatures $\left(87-137^{\circ} \mathrm{C}\right)$ of the eight saline spring water samples calculated by the quartz geothermometer are more reasonable. This is on average $67^{\circ} \mathrm{C}$ higher than the spring outlet temperatures and is in the range of the reservoir temperatures obtained from the multimineral equilibrium diagram. If the influence of cold-water mixing is removed, the real reservoir temperature should be slightly higher.

The heat of the saline springs in this study is derived from deep heat flow. The circulation depth can be roughly calculated with the following equation [76]:

$$
=G\left(T-T_{0}\right)+Z_{0}
$$

where $\mathrm{Z}$ is the circulation depth of the thermal groundwater in $\mathrm{m}, \mathrm{G}$ is the reciprocal of the geothermal gradient, $T$ is the reservoir temperature in ${ }^{\circ} \mathrm{C}, T_{0}$ is the annual average temperature in the study area in ${ }^{\circ} \mathrm{C}$, and $Z_{0}$ is the thickness of the constant temperature zone in $\mathrm{m}$. The $\mathrm{G}$ in north and central Laos was selected as $34.5 \mathrm{~m} /{ }^{\circ} \mathrm{C}$, which is similar to the $G$ value of the Simao Basin in southwestern Yunnan, China, that is located adjacent to this study area [133]. The $T$ is $21^{\circ} \mathrm{C}$, and the $Z_{0}$ is $25 \mathrm{~m}$. The saline springs in north and central Laos have experienced deep circulation, and that the circulation depths range from 2302 to $4027 \mathrm{~m}$ (see Table 3). Based on the estimated circulation depth of the saline springs and the geological conditions in north and central Laos, it is likely that the development of fractures and faults provided migration channels for the deep circulation of the saline spring water. It can also be inferred that the lowest position of saline spring deep water circulation may be the late Cretaceous salt-bearing strata, which are characterized by sandstone, siltstone, conglomerate, red-brown clayey siltstone, marl, beds of salt, gypsum, and anhydrite.

Table 3. Estimated reservoir temperatures of saline spring water samples from north and central Laos.

\begin{tabular}{cccccc}
\hline Sample ID & $\begin{array}{c}\text { Water } \\
\text { Temperature }\left({ }^{\circ} \mathbf{C}\right)\end{array}$ & & & Reservoir Temperature ( $\left.{ }^{\circ} \mathbf{C}\right)$ \\
& & Quartz & Na-K & Circulation \\
Depth (m)
\end{tabular}



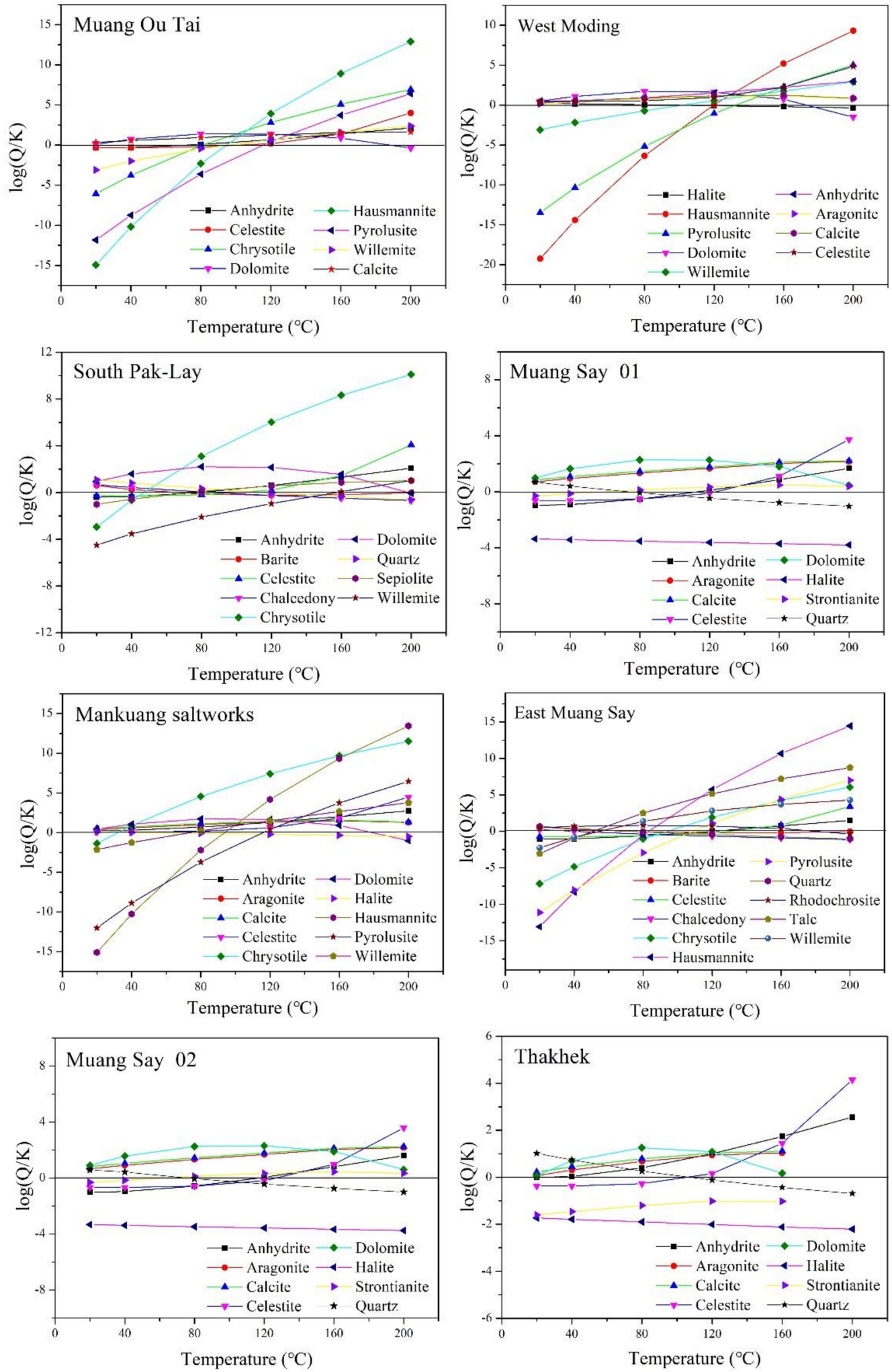

Figure 11. $\log (\mathrm{Q} / \mathrm{K})-\mathrm{T}$ diagram showing saline springs from the north and central Laos ( $\mathrm{Q}$ is the ion activity product; $\mathrm{K}$ is the equilibrium constant of the mineral at the equilibrium temperature).

\subsection{Potassium-Forming Prospect}

The $\gamma \mathrm{Na} / \gamma \mathrm{Cl}$ and $\mathrm{Br} \times 10^{3} / \mathrm{Cl}$ ratio can be used to distinguish brines in salt-bearing basins. Brines can be divided into sedimentary connate brine and salt-dissolution brines [76]. Sedimentary connate brines are the residual connate bittern brine that develops during 
evaporation and deposition of a saline basin. The continuous salinization during seepage of surface water or groundwater into the saline strata forms salt-dissolution brines. The $\gamma \mathrm{Na} / \gamma \mathrm{Cl}$ value of the sedimentary connate brines is generally lower than the standard seawater value (0.85), and the $\mathrm{Br} \times 10^{3} / \mathrm{Cl}$ value is generally greater than the standard seawater value (3.4). The ratio of $\gamma \mathrm{Na} / \gamma \mathrm{Cl}$ in salt-dissolution brines is around 1 or greater, and the $\mathrm{Br} \times 10^{3} / \mathrm{Cl}$ ratio is generally less than 1 and is caused by the lowlevel $\mathrm{Br}$ content in salt-dissolution brines [134]. The average $\gamma \mathrm{Na} / \gamma \mathrm{Cl}$ ratio of sylvinitedissolution brines is generally lower than 0.86 , and can even be lower. The $\gamma \mathrm{Na} / \gamma \mathrm{Cl}$ ratio and the $\mathrm{Br} \times 10^{3} / \mathrm{Cl}$ ratio of saline springs in this study varied from 0.84 to 0.99 , with an average of 0.93 , and from 0.23 to 0.55 , with an average of 0.36 , respectively. The $\gamma \mathrm{Na} / \gamma \mathrm{Cl}$ ratio is close to 1 , except for Muang Say (with an average $=0.85$ ), which is slightly less than 0.86 . The $\mathrm{Br} \times 10^{3} / \mathrm{Cl}$ ratio is less than 1 for all the samples. It can therefore be concluded that the saline springs in this study are salt-dissolution brines (saline water), which undergo salt dissolution processes. The saline springs in Muang Say may also have leached sylvinite and carnallite. Four hydrochemical characteristic coefficients are generally used to indicate the underground dissolution of potassium ores. The $\mathrm{K} \times 10^{3} / \Sigma_{\text {(Total salinity) }}$ and the $\mathrm{K} \times 10^{3} / \mathrm{Cl}$ ratios are direct indicators for potash exploration, while the $\mathrm{Br} \times 10^{3} / \mathrm{Cl}$ and the $\mathrm{Mg} \times 10^{2} / \mathrm{Cl}$ ratios are indirect indicators [135]. During the evaporation of seawater, $\mathrm{Br}$ is relatively enriched in the residual seawater during the deposition of $\mathrm{NaCl}$. The $\mathrm{Br} \times 10^{3} / \mathrm{Cl}$ ratio of brines can therefore determine the degree of concentration and evaporation of saline strata, which can indirectly guide potash exploration. There is a significant sylvite anomaly, which indicates a great possibility for potash exploration when $\mathrm{K} \times 10^{3} / \Sigma_{\text {(Total salinity) }}$ and $\mathrm{K} \times 10^{3} / \mathrm{Cl}$ ratios exceed 10 and 20, respectively [136]. The average values of indirect indicators $\left(0.25-0.28\right.$ for the $\mathrm{Br} \times 10^{3} / \mathrm{Cl}$ ratio and $\approx 1$ for the $\mathrm{Mg} \times 10^{2} / \mathrm{Cl}$ ratio) of spring waters. These indicators undergo incongruent dissolution of potassium-bearing halite and are greater than values $(<0.2$ for the $\mathrm{Br} \times 10^{3} / \mathrm{Cl}$ ratio and $<0.5$ for the $\mathrm{Mg} \times 10^{2} / \mathrm{Cl}$ ratio) that only undergo incongruent dissolution of halite [137]. The values of $\mathrm{K} \times 10^{3} / \Sigma_{\text {(Total salinity), }} \mathrm{K} \times 10^{3} / \mathrm{Cl}, \mathrm{Br} \times 10^{3} / \mathrm{Cl}$ and $\mathrm{Mg} \times 10^{2} / \mathrm{Cl}$ ratios for the eight saline spring water samples in this study ranged from $2.70-13.05$, with an average $=6.82,4.52-23.88$, with an average $=12.15,0.23-0.55$, with an average $=0.36$ and $0.06-0.9$, and with an average $=0.55$, respectively. A comprehensive analysis of the above indicators shows that the characteristic values of saline springs water in Muang Say is abnormal, which means that the prospects are relatively good for potash exploration in the Muang Say basin.

\subsection{Conceptual Model of Saline Spring Water Circulation}

The Muong Say basin in northern Laos, the Vientiane basin, and the Khammouane basin in southern Laos are important salt-bearing basins. They contain large amounts of saline spring water, late Cretaceous evaporites, and clastic deposits. The origin and evolution of the saline springs in north and central Laos are very complicated. We therefore propose a conceptual model for the circulation of the saline spring water in the study area (see Figure 12). A series of tectonic events after the late Cambrian formed the semi-graben salt-bearing basins in north and central Laos. Many marine salt-bearing strata were formed during the Mesozoic era. Based on water isotope analyses, the most likely recharge sources for saline springs in this study are rainfall and/or ice and snow melt from the surrounding mountains (Phu Bia, Phu Lay, Lao Bi, and Phu Miyang), while the Dien Bien Phu fault and other stretching tensile active faults can serve as favorable conduits for allowing groundwater circulation. The solute sources of the saline springs in this study are mainly be controlled by the dissolution of late Cretaceous marine evaporites (halite, gypsum/anhydrite, and carbonatite). The dissolution of carnallite and sylvite are the principal solute sources that control the chemistry of underground brines in Thakhek. The $\delta^{37} \mathrm{Cl}$ value of the saline springs in this study is controlled by atmospheric precipitation, water-rock interaction, and salt concentration via evaporation, while the $\delta^{11} \mathrm{~B}$ is mainly controlled by water-rock interaction. Saline springs have leached from the host rocks and flow along large fracture 
zones, through which they have experienced deep circulation, ranging in depth from 2302 to $4027 \mathrm{~m}$. The geothermal system that originates from the magmatic heat source then heats this water, after which further rock-water interaction occurs. The reservoir temperature range from $87-137^{\circ} \mathrm{C}$, as calculated by the quartz geothermometer, which is reasonable for the saline springs in this study.

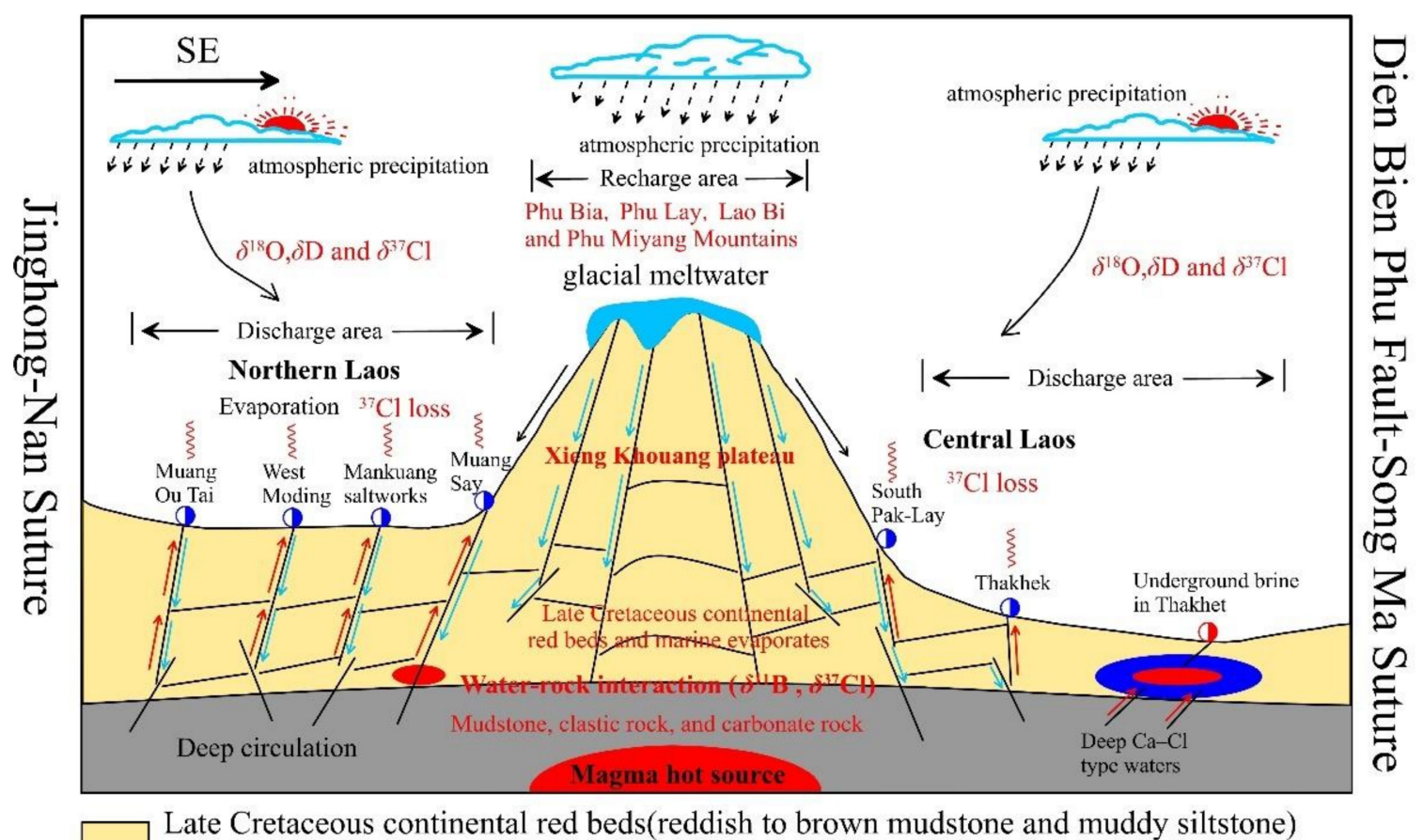
with evaporites (halite, anhydrite/gypsum, and potash layer)

Mudstone, clastic rock, and carbonate rock $\left(\mathrm{T}_{3}-\mathrm{K}_{1}\right)$

- Saline spring

$\curvearrowleft$ Stratum $\square$ Fault $\square$ Potash mining $\square$ Underground brine

Subsurface cold water flow

Subsurface hot water flow

Surface flow

Figure 12. Conceptual model of saline springs based on hydrochemistry, $\delta \mathrm{D}, \delta^{18} \mathrm{O}, \delta^{11} \mathrm{~B}$, and $\delta^{37} \mathrm{Cl}$.

\section{Conclusions}

We used chemical and stable isotopes $\left(\delta \mathrm{D}, \delta^{18} \mathrm{O}, \delta^{11} \mathrm{~B}\right.$, and $\left.\delta^{37} \mathrm{Cl}\right)$ of saline springs in north and central Laos to provide constraints on the solute process and recharge sources, the reservoir temperature, the mode of circulation, and the potash exploration prospects. The main findings include the following:

(1) Based on the major ionic components of saline springs in north and central Laos, the saline springs originated from the dissolution of late Cretaceous evaporites (halite, sulfate, and carbonate rocks) and underground brines in the potash mining area. The Thakhek is mainly influenced by the dissolution of carnallite and sylvite. Based on the $\delta \mathrm{D}$ and $\delta^{18} \mathrm{O}$ isotopic compositions, the saline springs may recharge by rainfall and/or ice and snow melt from the surrounding mountains, which underwent strong evaporation and intense rock-water interactions.

(2) The $\mathrm{Cl} / \mathrm{B}$ ratios and $\delta^{11} \mathrm{~B}$ values (ranging from 5.50 to $36.01 \%$ ) for the saline springs in this study vary significantly, confirming their continental origin. The main sources of the $B$ in the saline springs are probably marine carbonate rocks and marine evaporates (gypsum and halite). From the $\delta^{11} \mathrm{~B}-\mathrm{Cl} / \mathrm{B}$ diagram of thermal waters around the world, we conclude that the $\mathrm{B}$ in saline springs is primarily of a crustal source and does not have any marine or deep mantle sources. It is concluded here that $\mathrm{Cl} / \mathrm{Br}$ molar ratios (ranging from 4076 to 9853 ) and the stable $\mathrm{Cl}$ isotopes (ranging from -0.12 to +0.79 ) 
indicates that atmospheric precipitation and late cretaceous marine halite dissolution are the main halogen sources in the saline springs from north and central Laos.

(3) According to the multi-mineral equilibrium diagram and chemical geothermometers, the reservoir temperatures (ranging from $87-137^{\circ} \mathrm{C}$ ) for the saline springs calculated by the quartz geothermometer are reasonable. These saline springs have experienced deep circulation (ranging from 2302 to $4027 \mathrm{~m}$ deep). Hydrochemical characteristic coefficients show that the saline springs in the Muang Say basin could be dissolved by sylvinite and carnallite. We also suspect that the Muang Say basin has good potash exploration prospects.

Author Contributions: Conceptualization, X.Q. and H.M.; methodology, X.Z.; software, X.H. and G.L.; formal analysis, Z.J.; resources, H.C. and J.H.; data curation, Y.L. and W.M.; writing-original draft preparation, X.Q. and H.M.; writing—review and editing, W.H.; investigation, S.Y., Q.S., S.L. and H.W. All authors have read and agreed to the published version of the manuscript.

Funding: This research was funded by the Geological Resources and Geological Engineering Key Disciplines of Qinghai University (Grant No. 41250103) and the Qinghai Science and Technology Department (Grant No. 2021-ZJ-937Q). The fieldwork was supported by the Second Tibetan Plateau Scientific Expedition and Research Program (STEP), (Grant NO. 2019QZKK0805). Sincere appreciation goes to $\mathrm{Xu}$ Jianxin for their help in the fieldwork and to Wang Bo for their suggestions and help during lab experiments. We also thank Ren Erfeng, Xia Chulin, Zhou Shumin, and other staff members of the Department of Geological Engineering, Qinghai University, for their support and assistance in our study.

Data Availability Statement: The study did not report any data.

Conflicts of Interest: The authors declare no competing interest.

\section{References}

1. Wang, S. Paleotethyan evolution of the Indochina Block as deduced from granites in northern Laos. Gondwana Res. 2016, 38, 183-196. [CrossRef]

2. Racey, A. Mesozoic red bed sequences from SE Asia and the significance of the Khorat Group of NE Thailand. Geol. Soc. Lond. Spec. Publ. 2009, 315, 41-67. [CrossRef]

3. Racey, A.; Goodall, J. Palynology and stratigraphy of the Mesozoic Khorat Group red bed sequences from Thailand. Geol. Soc. Lond. Spec. Publ. 2009, 315, 69-83. [CrossRef]

4. Chen, H. Paleomagnetic evidence for clockwise rotation of the Simao region since the Cretaceous. A consequence of India-Asia collision. Earth Planet. Sci. Lett. 1995, 134, 203-217.

5. Tabakh, M.E.; Utha-Aroon, C.; Schreiber, B.C. Sedimentology of the Cretaceous Maha Sarakham evaporites in the Khorat Plateau of northeastern Thailand. Sediment. Geol. 1999, 123, 31-62. [CrossRef]

6. Shen, L.J.; Siritongkham, N. The characteristics, formation and exploration progress of the potash deposits on the Khorat Plateau, Thailand and Laos, Southeast Asia. China Geol. 2020, 3, 67-82. [CrossRef]

7. Tan, H.B. Strontium and boron isotopic constraint on the marine origin of the Khammuane potash deposits in southeastern. Chin. Sci. Bull. 2010, 55, 1-8. [CrossRef]

8. Li, M. Origins of the Mid-Cretaceous evaporite deposits of the Sakhon Nakhon Basin in Laos: Evidence from the stable isotopes of halite. J. Geochem. Explor. 2018, 184, 209-222. [CrossRef]

9. Clark, I.D.; Fritz, P. Environmental Isotopes in Hydrogeology; Lewis Publishing Company: Boca Raton, FL, USA, 1997.

10. Clayton, R.N. The origin of saline formation waters: 1. Isotopic composition. J. Geochem. Explor. 1966, 71, 3869-3882. [CrossRef]

11. Craig, H. Isotopic Variations in Meteoric Waters. Science 1961, 133, 1702-1703. [CrossRef]

12. Tan, H. Isotope and geochemical study for geothermal assessment of the Xining basin of the northeastern Tibetan Plateau. Geothermics 2012, 42, 47-55. [CrossRef]

13. Tan, H. Understanding the circulation of geothermal waters in the Tibetan Plateau using oxygen and hydrogen stable isotopes. Appl. Geochem. 2014, 51, 23-32. [CrossRef]

14. Hogan, J.F.; Blum, J.D. Boron and lithium isotopes as groundwater tracers: A study at the Fresh Kills Landfill, Staten Island, New York, USA. Appl. Geochem. 2003, 18, 615-627. [CrossRef]

15. Williams, L.B.; Hervig, R.L. Boron isotope composition of coals: A potential tracer of organic contaminated fluids. Appl. Geochem. 2004, 19, 1625-1636. [CrossRef]

16. He, M.Y. Accurate and Precise Determination of Boron Isotopic Ratios at Low Concentration by Positive Thermal Ionization Mass Spectrometry Using Static Multicollection of $\mathrm{Cs}_{2} \mathrm{BO}^{2+}$ Ions. Anal. Chem. 2013, 13, 6248-6253. [CrossRef] [PubMed]

17. Vengosh, A.; Gieskes, J.; Mahn, C. New evidence for the origin of hypersaline pore fluids in the Mediterranean basin. Chem. Geol. 2000, 163, 287-298. [CrossRef] 
18. Wei, H.Z. Boron isotope geochemistry of salt sediments from the Dongtai salt lake in Qaidam Basin: Boron budget and sources. Chem. Geol. 2014, 380, 74-83. [CrossRef]

19. Liu, W.G. Boron concentration and isotopic composition of halite from experiments and salt lakes in the Qaidam Basin. Geochem. Cosmochim. Acta 2000, 64, 2177-2183. [CrossRef]

20. Xiao, Y. Boron isotope method for study of seawater intrusion. Sci. China Ser. E 2001, 44, 62-71. [CrossRef]

21. Ishikawa, T.; Nakamura, E. Boron isotope systematics of marine sediments. Earth Planet. Sci. Lett. 1993, 117, 567-580. [CrossRef]

22. Barth, S. 11B/10B variations of dissolved boron in a freshwater-seawater mixing plume (Elbe Estuary, North Sea). Mar. Chem. 1998, 62, 1-14. [CrossRef]

23. Cary, L. Combining boron isotopes and carbamazepine to trace sewage in salinized groundwater: A case study in Cap Bon, Tunisia. Appl. Geochem. 2013, 34, 126-139. [CrossRef]

24. Vengosh, A. Boron Isotope Application for Tracing Sources of Contamination in Groundwater. Environ. Sci. Technol. 1994, 28, 1968-1974. [CrossRef] [PubMed]

25. Witherow, R.A.; Lyons, W.B.; Henderson, G.M. Lithium isotopic composition of the McMurdo Dry Valleys aquatic systems. Chem. Geol. 2010, 275, 139-147. [CrossRef]

26. Zhang, W. Boron geochemistry from some typical Tibetan hydrothermal systems: Origin and isotopic fractionation. Appl. Geochem. 2015, 63, 436-445. [CrossRef]

27. Pennisi, M. Chemical and isotopic (B, Sr) composition of alluvial sediments as archive of a past hydrothermal outflow. Chem. Geol. 2009, 266, 114-125. [CrossRef]

28. Zeng, Z. Boron isotope compositions of fluids and plumes from the Kueishantao hydrothermal field off northeastern Taiwan: Implications for fluid origin and hydrothermal processes. Mar. Chem. 2013, 157, 59-66. [CrossRef]

29. Siegel, K. Stable isotope (B, H, O) and mineral-chemistry constraints on the magmatic to hydrothermal evolution of the Varutrsk rare-element pegmatite (Northern Sweden). Chem. Geol. 2016, 421, 1-16. [CrossRef]

30. Eggenkamp, H.G.M.; Van Groos, A.K. Chlorine stable isotopes in carbonatites: Evidence for isotopic heterogeneity in the mantle. Chem. Geol. 1997, 140, 137-143. [CrossRef]

31. Banks, D.A.; Green, R.; Cliff, R.A.; Yardley, B.W.D. Chlorine isotopes in fluid inclusions: Determination of the origins of salinity in magmatic fluids. Geochim. Cosmochim. Acta 2000, 64, 1785-1789. [CrossRef]

32. Ito, E.; Harris, D.M.; Anderson, A.T., Jr. Alteration of oceanic crust and geologic cycling of chlorine and water. Geochim. Cosmochim. Acta 1983, 47, 1613-1624. [CrossRef]

33. Magenheim, A.J. Chlorine stable isotope composition of the oceanic crust: Implications for Earth's distribution of chlorine. Earth Planet. Sci. Lett. 1995, 131, 427-432. [CrossRef]

34. Liebscher, A.; Barnes, J.; Sharp, Z. Chlorine isotope vapor-liquid fractionation during experimental fluid-phase separation at $400{ }^{\circ} \mathrm{C} / 23 \mathrm{MPa}$ to $450{ }^{\circ} \mathrm{C} / 42 \mathrm{MPa}$. Chem. Geol. 2006, 234, 340-345. [CrossRef]

35. Barnes, J.D.; Cisneros, M. Mineralogical control on the chlorine isotope composition of altered oceanic crust. Chem. Geol. 2012, 326-327, 51-60. [CrossRef]

36. Selverstone, J.; Sharp, Z.D. Chlorine isotope constraints on fluid-rock interactions during subduction and exhumation of the Zermatt-Saas ophiolite. Geochem. Geophys. Geosyst. 2013, 14, 4370-4391. [CrossRef]

37. Eastoe, C.J.; Guilbert, J.M. Stable chlorine isotopes in hydrothermal processes. Geochim. Cosmochim. Acta 1992, 56, 4247-4255. [CrossRef]

38. Bonifacie, M. Chlorine isotopic compositions of high temperature hydrothermal vent fluids over ridge axes. Chem. Geol. 2005, 221, 279-288. [CrossRef]

39. John, T. Chlorine isotope evidence for crustal recycling into the Earth's mantle. Earth Planet. Sci. Lett. 2010, 298, 175-182. [CrossRef]

40. Wei, W.; Kastner, M.; Spivack, A. Reply to comment on: “Chlorine stable isotopes and halogen concentrations in convergent margins with implications for the $\mathrm{Cl}$ isotopes cycle in the ocean". Earth Planet. Sci. Lett. 2008, 274, 535. [CrossRef]

41. Musashi, M. Anion-exchange chromatographic study of the chlorine isotope effect accompanying hydration. J. Chromatogr. A 2007, 1140, 121-125. [CrossRef] [PubMed]

42. Xiao, Y.; Liu, W.; Zhang, C. The preliminary investigation on chlorine isotopic fractionation during the crystallization of saline minerals in salt lake. J. Salt Lake Res. 1994, 2, 35-40.

43. Tan, H.; Ma, H.; Xiao, Y.; Wei, H.; Zhang, X.; Ma, W. Characteristics of chlorine isotope distribution and analysis on sylvinite deposit formation based on ancient salt rock in the western Tarim Basin. Sci. China Ser. D 2005, 48, 1913-1920. [CrossRef]

44. Lu, Y. Geochemical study on boron isotopes in the Yangbajing geothermal field, Tibet. Sci. Geol. Sin. 2012, 47, 251-264.

45. Liu, M. Boron geochemistry of the geothermal waters from two typical hydrothermal systems in Southern Tibet (China): Daggyai and Quzhuomu. Geothermics 2019, 82, 190-202. [CrossRef]

46. Sherif, M.I.; Sultan, M.; Sturchio, N.C. Chlorine isotopes as tracers of solute origin and age of groundwaters from the Eastern Desert of Egypt. Earth Planet. Sci. Lett. 2019, 510, 37-44. [CrossRef]

47. Eastoe, C.J. Stable chlorine isotopes in halite and brine from the Gulf Coast Basin: Brine genesis and evolution. Chem. Geol. 2001, 176, 343-360. [CrossRef]

48. Leybourne, M.I.; Goodfellow, W.D. Br/Cl ratios and $\mathrm{O}, \mathrm{H}, \mathrm{C}$, and B isotopic constraints on the origin of saline waters from eastern Canada. Geochim. Cosmochim. Acta 2007, 71, 2209-2223. [CrossRef]

49. Musashi, M.; Oi, T.; Kreulen, R. Chlorine isotopic compositions of deep saline fluids in Ibusuki coastal geothermal region, Japan: Using B-Cl isotopes to interpret fluid sources. Isot. Environ. Health Stud. 2015, 51, 285-299. [CrossRef] [PubMed] 
50. Metcalfe, I. Palaeozoic-Mesozoic history of SE Asia. In The SE Asian Gateway: History and Tectonics of Australia-Asia Collision; Hall, R., Cottam, M., Wilson, M., Eds.; Geological Society, London, Special Publications: London, UK, 2011; Volume 355, pp. 7-35.

51. Wang, L. Provenance and paleogeography of the Late Cretaceous Mengyejing Formation, Simao Basin, southeastern Tibetan Plateau: Whole-rock geochemistry, U-Pb geochronology, and Hf isotopic constraints. Sediment. Geol. 2014, 304, 44-58. [CrossRef]

52. Metcalfe, I. Gondwana dispersion and Asian accretion: Tectonic and palaeogeographic evolution of eastern Tethys. J. Asian Earth Sci. 2013, 66, 1-33. [CrossRef]

53. Tapponnier, P. Propagating extrusion tectonics in Asia: New insights from simple experiments with plasticine. Geology 1982, 10, 611. [CrossRef]

54. Sone, M.; Metcalfe, I. Parallel Tethyan sutures in mainland Southeast Asia: New insights for Palaeo-Tethys closure and implications for the Indosinian orogeny. C. R. Geosci. 2008, 340, 166-179. [CrossRef]

55. Metcalfe, I. Tectonic framework and Phanerozoic evolution of Sundaland. Gondwana Res. 2011, 19, 3-21. [CrossRef]

56. Qu, Y.H. Potash-Forming Rules and Prospect of the Lower Tertiary in the Lanping-Simao Basin, Yunnan; Geological Publishing House: Beijing, China, 1998; pp. 1-118, (In Chinese with English Abstract).

57. Jian, P. Devonian to Permian plate tectonic cycle of the Paleo-Tethys Orogen in southwest China (II): Insights from zircon ages of ophiolites, arc/back-arc assemblages and within-plate igneous rocks and generation of the Emeishan CFB province. Lithos 2009, 113, 767-784. [CrossRef]

58. Metcalfe, I. Late Palaeozoic and Mesozoic tectonic and palaeogeographical evolution of SE Asia. Geol. Soc. Lond. Spec. Publ. 2009, 315, 7-23. [CrossRef]

59. Hite, R.J.; Japakasetr, T. Potash deposits of the Khorat Plateau, Thailand and Laos. Econ. Geol. 1979, 74, 448-458. [CrossRef]

60. Wang, L. First SHRIMP U-Pb zircon ages of the potash-bearing Mengyejing Formation, Simao Basin, southwestern Yunnan, China. Cretac. Res. 2015, 52, 238-250. [CrossRef]

61. Geological and Mineral Occurrence Map. 1:1,000,000 Scale; British Geological Survey and Department of Geology and Mines: Nottingham, UK, 1991.

62. Singsoupho, S.; Bhongsuwan, T.; Elming, S.A. Palaeocurrent direction estimated in Mesozoic redbeds of the Khorat Plateau, Lao PDR, Indochina Block using anisotropy of magnetic susceptibility. J. Asian Earth Sci. 2015, 106, 1-18. [CrossRef]

63. Hérail, G.F. The structural evolution of Triassic intermontane basins in Northeastern Thailand. In Proceedings of the International Symposium on Intermontane Basins: Geology and Resources, Chiang Mai, Thailand, 30 January 1989; pp. $231-242$.

64. Fenton, C.H. Late Quaternary faulting in northern Thailand. In Proceedings of the International Conference of Stratigraphy \& Tectonic Evolution of Southeast Asia \& South Pacific, Bangkok, Thailand, 19-24 August 1997.

65. Zhang, X.Y. Late Cretaceous potash evaporites in Savannakhet Basin of Middle Laos: Geochemical evidences of nonmarine inputs. Acta Petrol. Sin. 2015, 31, 2783-2792, (In Chinese with English Abstract).

66. Qin, Z. Origin of Underground Brine in Potassium-Bearing Strata in Khammouane, Central Laos. Geochem. Int. 2019, 57, 1327-1338.

67. Xiying, Z. Stable Isotope and Element Geochemistry of Saline Springs in Evaporite-bearing Mengla Basin, South Yunnan, China. Acta Geol. Sin-Eng. 2014, 1, 176-177.

68. Zhang, Y. Characterization of a saline hot spring depositing travertine in the red beds in the Simao Basin of China. Hydrogeol. J. 2020, 28, 1431-1447. [CrossRef]

69. Ngansom, W.; Dürrast, H. Saline hot spring in Krabi, Thailand: A unique geothermal system. In SEG Technical Program Expanded Abstracts; Society of Exploration Geophysicists: Tulsa, OK, USA, 2016.

70. Xiao, Y.K.; Zhou, Y.M.; Liu, W.G. Precise Measurement of Chlorine Isotopes Based on $\mathrm{Cs}_{2} \mathrm{Cl}_{2}$ by Thermal Ionization Mass Spectrometry. Anal. Lett. 1995, 28, 1295-1304. [CrossRef]

71. Fan, Q.S. Boron occurrence in halite and boron isotope geochemistry of halite in the Qarhan Salt Lake, western China. Sediment. Geol. 2015, 322, 34-42. [CrossRef]

72. Xiao, Y.K. A secondary isotopic reference material of chlorine from selected seawater. Chem. Geol. 2002, 182, 655-661. [CrossRef]

73. Luo, C. Stable isotope fractionation of chlorine during the precipitation of single chloride minerals. Appl. Geochem. 2014, 47, 141-149. [CrossRef]

74. MGMR. Hydrogeological Manual, Hydrogeological Engineering and Geological Technique Research Team, Ministry of Geology and Mineral Resources; Geology Publishing House: Beijing, China, 1983; pp. 105-108. (In Chinese)

75. Araguás-Araguás, L.; Froehlich, K.; Rozanski, K. Stable isotope composition of precipitation over southeast Asia. J. Geophys. Res.-Atmos. 1998, 103, 28721-28742. [CrossRef]

76. Zhou, X. Special Topics on Groundwater Sciences, 2nd ed.; Geological Publishing House: Beijing, China, 2017. (In Chinese)

77. Yu, J. Isotope Geochemistry of China; Science Press: Beijing, China, 1997. (In Chinese)

78. Bo, Y.; Liu, C.; Zhao, Y.; Wang, L. Chemical and isotopic characteristics and origin of spring waters in the Lanping-Simao Basin, Yunnan, Southwestern China. Geochem. Interdiscip. J. Chem. Probl. Geosci. Geoecol. 2015, 75, 287-300. [CrossRef]

79. Carpenter, A.B. Origin and chemical evolution of brines in sedimentary basin. In SPE Annual Fall Technical Conference and Exhibition; Society of Petroleum Engineers: Houston, TX, USA, 1978; pp. 60-77.

80. Fontes, J.C.; Matray, J.M. Geochemistry and origin of formation brines from the Paris Basin, France: 1 . Brines associated with Triassic salts. Chem. Geol. 1993, 109, 149-175. [CrossRef] 
81. Cerling, T.E.; Pederson, B.L.; Damm, K.V. Sodium-calcium ion exchange in the weathering of shales: Implications for global weathering budgets. Geology 1989, 17, 552-554. [CrossRef]

82. Gao, X. Mineralogical and geochemical characteristics and genesis of the potassium-magnesium salt deposit in Khammouan Province, Laos. Acta Petrol. Mineral. 2012, 31, 578-588, (In Chinese with English Abstract).

83. Kharaka, Y. Geochemistry of metal-rich brines from central Mississippi salt dome basin, USA. Appl. Geochem. 1987, 2, 543-561. [CrossRef]

84. Walter, L.M.; Stueber, A.M.; Huston, T.J. Br-Cl-Na systematics in Illinois basin fluids: Constraints on fluid origin and evolution. Geology 1990, 18, 315-318. [CrossRef]

85. Zhang, Y.; Zhou, X.; Liu, H.; Yu, M.; Hai, K.; Tan, M.; Huo, D. Hydrogeochemistry, Geothermometry, and Genesis of the Hot Springs in the Simao Basin in Southwestern China. Geofluids 2019, 1423, 1-23. [CrossRef]

86. Risacher, F.; Alonso, H. Geoquimica del Salar de Atacama: 2. Evolucion de las aguas. Rev. Geol. Chile 1996, $23,123-134$.

87. Risacher, F.; Alonso, H.; Salazar, C. The origin of brines and salts in Chilean salars: A hydrochemical review. Earth Sci. Rev. 2003, 63, 249-293. [CrossRef]

88. Lowenstein, T.K.; Risacher, F. Closed basin brine evolution and the influence of Ca-Cl inflow waters: Death Valley and Bristol Dry Lake California, Qaidam Basin, China, and Salar de Atacama, Chile. Aquat. Geochem. 2009, 15, 71-94. [CrossRef]

89. Gou, G.N.; Wang, Q.; Wyman, D.A.; Xia, X.P.; Wei, G.J.; Guo, H.F. In situ boron isotopic analyses of tourmalines from Neogene magmatic rocks in the northern and southern margins of Tibet: Evidence for melting of continental crust and sediment recycling. Solid Earth 2017, 2, 43-54. [CrossRef]

90. Schwarcz, H.P.; Agyei, F.K.; Mcmullen, C.C. Boron isotopic fractionation during clay adsorption from sea-water. Earth Planet. Sci. Lett. 1969, 6, 1-5. [CrossRef]

91. Spivack, A.J.; Edmond, J.M. Boron isotope exchange between seawater and the oceanic crust. Geochim. Cosmochim. Acta 1987, 51, 1033-1043. [CrossRef]

92. Marschall, H.R.; Shao, J. Tourmaline isotopes: No element le behind. Elements 2011, 7, 313-319. [CrossRef]

93. Vengosh, A. Boron isotope variations during fractional evaporation of sea water: New constraints on the marine vs. nonmarine debate. Geology 1992, 20, 99-802. [CrossRef]

94. Barth, S. Boron isotope variations in nature: A synthesis. Geochim. Cosmochim. Acta 1993, 82, 640-651. [CrossRef]

95. Lü, Y. Geochemical processes and origin of boron isotopes in geothermal water in the Yunnan-Tibet geothermal zone. Sci. China Earth Sci. 2014, 57, 2934-2944. [CrossRef]

96. Vengosh, A. Boron isotope geochemistry as a tracer for the evolution of brines and associated hot springs from the Dead Sea, Israel. Geochim. Cosmochim. Acta 1991, 55, 1689-1695. [CrossRef]

97. Chatterjee, S. A multi-isotope approach $(\mathrm{O}, \mathrm{H}, \mathrm{C}, \mathrm{S}, \mathrm{B}$ and $\mathrm{Sr})$ to understand the source of water and solutes in some the thermal springs from West Coast geothermal area, India. Arab. J. Geosci. 2017, 10, 242. [CrossRef]

98. Oi, T.; Ogawa, J.; Ossaka, T. Boron isotopic compositions of Shimogamo hot springs, Izu, Japan. Geochem. J. 2008, 27, 147-154. [CrossRef]

99. Aggarwal, J.K. Precise and accurate determination of boron isotope ratios by multiple collector ICP-MS: Origin of boron in the Ngawha geothermal system, New Zealand. Chem. Geol. 2003, 199, 331-342. [CrossRef]

100. Romain Millot, A.H. Geothermal waters from the Taupo Volcanic Zone; New Zealand: A view through Li, B and Sr isotopes. In Proceedings of the 9th International Symposium on Applied Isotope Geochemistry, Tarragona, Spain, 18-23 September 2011.

101. Aggarwal, J.K. The boron isotope systematics of Icelandic geothermal waters: 1. Meteoric water charged systems. Geochim. Cosmochim. Acta 2000, 64, 579-585. [CrossRef]

102. Palmer, M.; Sturchio, N. The boron isotope systematics of the Yellowstone National Park (Wyoming) hydrothermal system: A reconnaissance. Geochim. Cosmochim. Acta 1990, 54, 2811-2815. [CrossRef]

103. Purnomo, B.J.; Pichler, T.; You, C.-F. Boron isotope variations in geothermal systems on Java, Indonesia. J. Volcanol. Geotherm. Res. 2016, 311, 1-8. [CrossRef]

104. Millot, R.; Négrel, P.; Petelet-Giraud, E. Multi-isotopic (Li, B, Sr, Nd) approach for geothermal reservoir characterization in the Limagne Basin (Massif Central, France). Appl. Geochem. 2007, 22, 2307-2325. [CrossRef]

105. Vengosh, A.; Kolodny, Y.; Starinsky, A.; Chivas, A.R.; McCulloch, M.T. Coprecipitation and isotopic fractionation of boron in modern biogenic carbonates. Geochim. Cosmochim. Acta 1991, 55, 2901-2910. [CrossRef]

106. Jiang, S.Y. Boron Isotope and Its Geological Applications. J. China Univ. Geosci. 2000, 6, 1-16. (In Chinese)

107. Zhang, Y. Geochemical constraint on origin and evolution of solutes in geothermal springs in western Yunnan, China. Geochemistry 2016, 76, 63-75. [CrossRef]

108. Slack, J.F.; Palmer, M.R. Boron isotopic composition of tourmaline from massive sulfide deposits and tourmalinites. Mineral. Petrol. 1989, 103, 434-451.

109. Xiwei, Q. Geochemical Constraints on the Origin and Evolution of Spring Waters in the Changdu-Lanping-Simao Basin, Southwestern China. Acta Geol. Sin. 2019, 93, 1097-1112.

110. Chaussidon, M.; Marty, B. Primitive boron isotope composition of the mantle. Science 1995, 269, 383-386. [CrossRef]

111. Xiao, J. Progress of geochemical application of boron isotope. Mar. Geol. 2012, 9, 20-33.

112. Kaufmann, R.S. Chlorine stable isotope distribution of Michigan Basin formation waters. Geochemistry 1993, 8, 403-407. [CrossRef] 
113. Lyons, W.B.; Frape, S.K.; Welch, K.A. History of McMurdo Dry Valley lakes, Antarctica, from stable chlorine isotope data. Geology 1999, 27, 527-530. [CrossRef]

114. Yingkai, X. Variations in isotopic compositions of chlorine in evaporation-controlled salt lake brines of Qaidam Basin, China. Chin. J. Oceanol. Limnol. 2000, 18, 169-177. [CrossRef]

115. Eggenkamp, H. Chlorine stable isotope fractionation in evaporites. Geochim. Cosmochim. Acta 1995, 59, 5169-5175. [CrossRef]

116. Vengosh, A.; Chivas, A.R.; Mcculloch, M.T. Direct determination of boron and chlorine isotopic compositions in geological materials by negative thermal-ionization mass spectrometry. Chem. Geol. Isot. Geosci. 1989, 79, 333-343. [CrossRef]

117. Bodnar, R.J. Synthetic fluid inclusions: XII. The system $\mathrm{H}_{2} \mathrm{O} \mathrm{NaCl}$. Experimental determination of the halite liquidus and isochores for a $40 \mathrm{wt} \% \mathrm{NaCl}$ solution. Geochim. Cosmochim. Acta 1994, 58, 1053-1063. [CrossRef]

118. Chi, G.; Savard, M. Sources of basinal and Mississippi Valley-type mineralizing brines: Mixing of evaporated seawater and halite-dissolution brine. Chem. Geol. 1997, 143, 121-125. [CrossRef]

119. Grandia, F. Geochemistry of the Fluids Related to Epigenetic Carbonate-Hosted Zn-Pb Deposits in the Maestrat Basin, Eastern Spain: Fluid Inclusion and Isotope (Cl, C, O, S, Sr) Evidence. Econ. Geol. 2003, 98, 933-954. [CrossRef]

120. Eggenkamp, H.G.M.; Schuiling, R.D. $837 \mathrm{C} 1$ variations in selected minerals: A possible tool for exploration. J. Geochem. Explor. 1995, 55, 249-255. [CrossRef]

121. Koehler, G.; Wassenaar, L.I. The stable isotopic composition $(37 \mathrm{Cl} / 35 \mathrm{Cl})$ of dissolved chloride in rainwater. Geochemistry 2010, 25 , 91-96. [CrossRef]

122. Kaufmann, R. Natural chlorine isotope variations. Nature 1984, 309, 338-340. [CrossRef]

123. Eastoe, C.J.; Dettman, D.L. Isotope amount effects in hydrologic and climate reconstructions of monsoon climates: Implications of some long-term data sets for precipitation. Chem. Geol. 2016, 430, 78-89. [CrossRef]

124. Zhang, K.; Ma, H. Discussion on the origins of hot spring along the coast of South China. Acta Sci. Nat. Univ. Sunyatseni Nat. Sci. 2002, 41, 82-86. (In Chinese)

125. Ellis, A.J. Quantitative interpretation of chemical characteristics of hydrothermal systems. Geothermics 1970, 2 Pt 1, 516-528. [CrossRef]

126. Wang, J. Low-Medium Temperature Convective Geothermal System; Science Press: Beijing, China, 1993. (In Chinese)

127. Giggenbach, W.F. Geothermal solute equilibria. Derivation of Na-K-Mg-Ca geoindicators. Geochim. Cosmochim. Acta 1988, 52, 2749-2765. [CrossRef]

128. Rybach, L.; Muffler, L. Geothermal Systems: Principles and Case Histories; Wiley-Interscience: Chichester, UK; New York, NY, USA, 1981; Volume 371.

129. Truesdell, A.H. Summary of section III, Geochemical techniques in exploration. In Proceedings of the Second United Nations Symposium on the Development and Use of Geothermal Resources, San Francisco, CA, USA, 20-29 May 1975; Volume 1, pp. 731-739.

130. Fournier, R.O. Geochemical and hydrologic considerations and the use of enthalpy-chloride diagrams in the prediction of underground conditions in hot-spring systems. J. Volcanol. Geotherm. Res. 1979, 5, 1-16. [CrossRef]

131. Zhao, C.P. Mantle-Derived Helium Release Characteristics and Deep Magma Chamber Activities of Present Day in the Tengchong Volcanic Area. Ph.D. Thesis, Institute of Geology, State Seismological Bureau, Beijing, China, 2008.

132. Reed, M.; Spycher, N. Calculation of $\mathrm{pH}$ and mineral equilibria in hydrothermal waters with application to geothermometry and studies of boiling and dilution. Geochim. Cosmochim. Acta 1983, 48, 1479-1492. [CrossRef]

133. Xu, Q. Terrestrial heat flow and its tectonic significance in Yunnan, China. Geotectonica et Metallogenia 1992, 16, 285-299. (In Chinese)

134. Lin, Y. Geochemical characteristics of potassium-rich basin in Middle Triassic Chengdu salt basin of Sichuan Basin and its prospects for brine tapping. Geol. Chem. Miner. 2002, 24, 72-84. (In Chinese)

135. Zhang, Y. Hydrogeological characteristics of the hot springs and salty springs occurring in the redbeds in the Lanping-Simao Basin of Yunnan. Hydrogeol. Eng. Geol. 2018, 45, 40-48.

136. Zhang, J.; Li, G. Mengyejing potash deposit in Jiangcheng, Yunnan. In Potash Geological Scientific Research Team of Yunnan Geological Bureau: A Potash Geological Research Symposium in Simao, Yunnan; Yunnan Geological Bureau: Kunming, China, 1980; Volume 3, pp. 38-44. (In Chinese)

137. Bureau of Geology and Mineral Resources of Gansu Province. Geology of the Saline Deposits in Simao District, Yunnan; Geological Publishing House: Beijing, China, 1986. (In Chinese) 